African Crop Science Journal by African Crop Science Society is licensed under a Creative Commons Attribution 3.0 Uganda License. Based on a work at www.ajol.info/ and www.bioline.org.br/cs DOI: https://dx.doi.org/10.4314/acsj.v27i4.4

\title{
VALIDATION OF EFFECTIVENESS MARKER-ASSISTED GAMETE SELECTION FOR MULTIPLE DISEASE RESISTANCE IN COMMON BEAN
}

\author{
M.J. MONDO ${ }^{1,2}$, P.M. KIMANI ${ }^{1}$ and R.D. NARLA ${ }^{1}$
}

${ }^{1}$ Department of Plant Science and Crop Protection, University of Nairobi, P. O. Box 29053-00625, Nairobi, Kenya

${ }^{2}$ Faculty of Agriculture and Environmental Sciences, Université Evangélique en Afrique (UEA), P. O. Box 3323, Bukavu, Democratic Republic of Congo

Corresponding author: mondo.mubalama@yahoo.fr,mondo.mubalama@uea.ac.cd

(Received 23 January 2019; accepted 30 October 2019)

\begin{abstract}
Plant breeding is the most cost-effective, practical and environmentally friendly strategy for reducing losses associated with bean diseases, especially in low-input agricultural systems because no additional investment is required from farmers. However, incorporating resistance to one pathogen may not result in a significant change because several diseases co-infection beans at the farm level. Consequently, breeding varieties with multiple disease resistance is a more appropriate, reliable and sustainable approach. In such context, gamete selection is the more appropriate breeding method because it allows simultaneous selection for multiple traits; though as originally proposed and validated, it is largely based on phenotypic evaluation for agronomic traits, which leads to delay in variety development and strong dependence on erratic weather conditions. The objective of this study was to validate $26 \mathrm{~F}_{18}$ elite bean lines selected for resistance to angular leaf spot (ALS), anthracnose, root rots, common bacterial blight (CBB) and bean common mosaic virus (BCMV), from inter-racial and inter-gene pool populations developed using molecular markers on the gamete selection method in early generations. Pathogens were isolated from diseased plants collected from various locations in central Kenya, multiplied on appropriate media and used to inoculate the test lines in a greenhouse at Kabete Field Station, University of Nairobi. Data on disease incidence and severity were collected at $14,21,28^{\text {th }}$ days after inoculation, using the 1-9 CIAT scale; except for the root rot experiments for which data were recorded once at $21^{\text {st }}$ day after seedling emergence. Results showed that five of the 26 elite lines possessed multiple resistance to five pathogens, eight to four pathogens, nine to three pathogens, three to two pathogens and one was resistant to one pathogen. This implied that markers, used in early generations, were effective in the identification and transfer of resistance genes to susceptible commercial varieties. However, there were no significant correlations in the reaction of tested genotypes to pathogens in this study, except between BCMV and ALS ( $r=0.3942 *)$. This suggests that resistance genes are in different chromosomes and are assorted independently. The presence of genotypes with multiple disease resistance among test elite lines, confirms the effectiveness
\end{abstract}


of inter-racial crosses and marker-assisted gamete selection to concurrently improve the resistance to common bean major diseases in Eastern Africa.

Key Words: Inter-racial elite lines, Kenya, Phaseolus vulgaris

\section{RÉSUMÉ}

L'amélioration génétique des plantes est la stratégie la moins coûteuse, la plus pratique et la plus respectueuse de l'environnement dans la réduction des pertes associées aux maladies du haricot, en particulier dans les systèmes agricoles à faible usage d'intrants. Ceci car aucun investissement supplémentaire n'est requis de la part des agriculteurs. Cependant, l'incorporation de la résistance à un agent pathogène ne pourrait entrainer de changement significatif, car plusieurs maladies attaquent simultanément le haricot. Par conséquent, le développement de variétés présentant une résistance multiple aux maladies constitue une approche plus appropriée, fiable et durable. Dans ce contexte, la sélection des gamètes est la méthode d'amélioration génétique la plus appropriée car elle permet la sélection simultanée de plusieurs caractères ; bien que, telle que proposée et validée à l'origine, elle repose en grande partie sur une évaluation phénotypique des caractères agronomiques. Ceci retarde ainsi le développement de la variété et entraîne une forte dépendance à des conditions météorologiques, souvent irrégulières. L'objectif de cette étude était de valider la huitième génération $\left(\mathrm{F}_{1.8}\right)$ de 26 lignées élites de haricot sélectionnées pour leur résistance à la maladie des taches angulaires, à l'anthracnose, à la fonte des semis, à la bactériose commune du haricot et à la mosaïque commune du haricot. Ces lignées viennent des populations interraciales et inter-géniques de haricot, développées en utilisant des marqueurs moléculaires sur la méthode de sélection des gamètes dans leurs premières générations. Des agents phytopathogènes ont été isolés à partir de plantes malades recueillies à divers endroits dans la partie centrale du Kenya, multipliés sur des milieux de culture appropriés et utilisés par la suite pour inoculer les lignées testées sous une serre, dans le champ expérimental de l'Université de Nairobi situé à Kabete. Les données sur l'incidence et la sévérité des maladies ont été enregistrées aux 14, 21

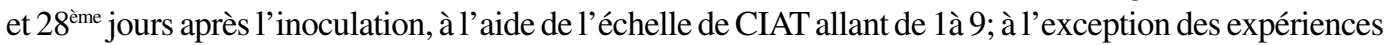
sur les fontes de semis pour lesquelles les données étaient enregistrées une seule fois, au $21^{\text {ème }}$ jour après la levée des plantules. Les résultats ont montré que cinq des 26 lignées élites présentaient une résistance multiple à cinq agents pathogènes, huit à quatre agents pathogènes, neuf à trois agents pathogènes, trois à deux agents pathogènes et une était résistante à un agent pathogène. Cela démontrait que les marqueurs moléculaires, utilisés dans les premières générations, étaient efficaces dans l'identification et le transfert de gènes de résistance à des variétés commerciales sensibles. Cependant, il n'y avait pas de corrélations significatives dans la réaction des génotypes aux agents pathogènes, sauf entre la mosaïque commune du haricot et la maladie des taches angulaires $(r=0,3942 *)$. Ceci suggère que les gènes de résistance sont dans différents chromosomes et assortis indépendamment. La présence de génotypes, présentant une résistance multiple aux maladies parmi les lignées élites testées, confirme l'efficacité des croisements interraciaux et de la méthode de sélection de gamètes assistée par marqueurs dans l'amélioration simultanée de la résistance aux principales maladies du haricot commun en Afrique de l'Est.

Mots Clés: Lignées élites interraciales, Kenya, Phaseolus vulgaris

\section{INTRODUCTION}

Common bean (Phaseolus vulgaris L.) is the most important legume crop for human consumption worldwide, contributing protein, complex carbohydrates, dietary fiber, isoflavones and micronutrients (iron, phosphorus, zinc) to diets of large millions of people, especially in Africa and Latin America (Broughton et al., 2003; Beebe et al., 2013). 
In addition to its nutritional value, the common bean is also an important source of income for the small-scale and resource-poor farmers of sub-Saharan Africa (CGIAR, 2017). Also, common bean has multiple health benefits; it reduces the risk of chronic diseases such as diabetes, heart disease and cancer (Winham $e t$ al., 2018).

Eastern and Central African countries are the major producers and consumers of common bean in Africa, where it contributes up to $25 \%$ of total caloric intake and $45 \%$ of total dietary protein and, thus, making it the highest level of contribution of protein in the world (Kilimo Trust, 2012; Alladassi et al., 2018). Kenya, Tanzania and Uganda are the leading producers in Africa (Beebe et al., 2013; FAO, 2018). However, Kenya has been a net bean importer for the last two decades because demand exceeds production (Kimani et al., 2005a).

Despite the importance of common bean in Eastern and Central Africa, its productivity is still among the lowest in the world, with an average seed yield of $0.5 \mathrm{t} \mathrm{ha}^{-1}$ (FAO, 2018); while potential yields range from 1 to $3 \mathrm{tha}^{-1}$ for bush genotypes, and could be as high as 5 t ha ${ }^{-1}$ for climbers (Ronner et al., 2018). Many constraints are responsible for poor performance of common bean in the region. Major constraints include drought stress, low soil fertility, plant diseases and pests, poor adaptation of introduced varieties to local conditions, and socio-economic factors such as low and untimely access to external inputs; and poor farming practices (Wortmann et al., 1998; Kimani et al., 2005b).

The major diseases constraining common bean productivity in Eastern and Central Africa include angular leaf spot (ALS) caused by Pseudocercospora griseola (Sacc.) (Ddamulira et al., 2014; Leitich et al., 2016) and anthracnose (Colletotrichum lindemuthianum (Sacc. and Magn.) (Kiryowa et al., 2016). Other damaging diseases are root rots (Pythium spp., Fusarium spp., Sclerotium rolfsii and Rhizoctonia solani) (Nzungize et al., 2011a; Obala et al., 2012; Buruchara et al., 2015; Mukankusi et al., 2018), bean common mosaic and necrotic viruses (BCMV/ BCMNV) (Mwaipopo et al., 2017), and common bacterial blight (CBB) caused by Xanthomonas axonopodis pv. phaseoli (Alladassi et al., 2018). These diseases cause severe losses of seed yield and quality of common bean, ranging from $20 \%$ to as high as 80 to $100 \%$ (Singh and Schwartz, 2010). Wortmann et al. (1998) estimated the annual production losses in Eastern Africa caused by ALS at 281,300 t; anthracnose at 247,400 t, root rot at 179,800 t, CBB at 145,900 $\mathrm{t}$ and BCMV at $144,600 \mathrm{t}$.

Several approaches have been used to control those common bean diseases, such as combinations of cultural and chemical controls; but are occasionally found to be ineffective to many diseases (Okii et al., 2017). In addition to negative environmental impacts of chemicals, associated costs are not practical for the widespread low-input systems; and therefore, breeding for resistance is the most cost-effective and environmentally friendly approach for resource-poor farmers of Eastern and Central Africa (Odogwu et al., 2017), since there is often no additional cost. This approach can greatly reduce the need for chemicals, hence increasing returns on farmers' investment.

Okii et al. (2017) showed that multiple pathogen co-infections on common beans are responsible for complete crop losses in susceptible bean varieties. This suggests that common bean breeding for disease resistance should target multiple pathogens simultaneously, by pyramiding resistance genes in a single genotype for a broader and durable resistance. Because several diseases normally occur in a particular production environment, incorporating resistance to a single disease will not result in significant changes (Singh, 1994; Kimani et al., 2005b).

Development of improved dry bean varieties in Eastern and Central Africa faces four key challenges. First, is the occurrence 
of new races and strains of disease pathogens, such as ALS, anthracnose, root rots, and BCMV (Leitich et al., 2016; Mwaipopo et al., 2017). In addition, there is insufficient identification and deployment of new sources of resistance to the emerging pathotypes (Ddamulira et al., 2014; Mukankusi et al., 2018), as well as a narrow genetic base within existing breeding populations, especially for grain yield potential and disease resistance. This threatens progress towards improvement for these traits (Kimani et al., 2005b; Asfaw et al., 2009). Finally, there is also lower efficiency of breeding methodology (Kimani et al., 2005b) leading to high failure rate and longer duration in new varieties development process. These four issues listed above were the main focus of the marker-assisted breeding programme at the University of Nairobi since 2009. The programme initiated studies to determine whether marker-assisted gamete selection could be effective in pyramiding genes for resistance to bean major diseases in Eastern and Central Africa (mainly ALS, anthracnose, CBB, BCMV and root rot); and introduce these genes into susceptible, but popular large- and small-seeded bean varieties (Musyimi, 2014; Njuguna, 2014; Mondo et al., 2018).

Thirty-two inter-racial and inter-gene pool populations were developed from crosses among Middle American (Mesoamerican) and Andean gene pool cultivars to broaden the genetic base of commercial cultivars, and take advantage of attributes of both gene pools. In addition to high yield potential of Middle American cultivars, they are resistant to major diseases of the Andean gene pool counterparts, and possess genes for drought resistance; while the Andean cultivars are the most preferred in Africa for their seed quality, and thus fetch higher prices in local markets (Welsh et al., 1995; Singh et al., 2002; Sichilima et al., 2016).

This, therefore, justified the necessity of inter-racial crosses in developing breeding populations. To shorten the breeding programme and increase its efficiency, the marker-assisted gamete selection method was followed as a possible improvement of the original phenotypic gamete selection developed by Singh (1994). Based on the objective of the breeding programme in the present study, gamete selection is the more appropriate breeding method because it allows simultaneous selection for multiple traits (Beaver and Osorno, 2009) and screening and selection of desirable traits in early generations, and therefore, helps to avoid wastage of scarce resources and time by advancing unpromising genotypes as it is the case for most bean breeding methods.

This study, which is a continuation of the above described breeding programme, aimed to validating the multiple disease resistance of $\mathrm{F}_{1.8}$ elite bean lines selected in early generations by combining molecular markers to the gamete selection on populations from inter-racial crosses.

\section{MATERIALS AND METHODS}

Study site. This study was carried out at Kabete Field Station of the University of Nairobi, which is located in Kenya at coordinates $01^{\circ} 15^{\prime} \mathrm{S}$ (latitude); 036 44' $\mathrm{E}$ (longitude) and at an altitude of approximately $1820 \mathrm{~m}$ above sea level. The station receives an average rainfall of $1059 \mathrm{~mm}$ annually, spread over two seasons. It experiences mean maximum and minimum temperatures of 22.5 ${ }^{\circ} \mathrm{C}$ and $12.3{ }^{\circ} \mathrm{C}$, respectively. Soils are well drained, very deep, dark reddish brown, friable clay with acid humic topsoil, humic nitisols (Jaetzold et al., 2006). The $\mathrm{pH}$ is about 5.0 to 5.4 and a mean sunshine of 6.6 hours per day.

Plant materials. Plant materials used for this study were 26 elite $\mathrm{F}_{1.8}$ lines selected for seed yield and seed quality from multisite testing, conducted during 2017 short rainy season in three agro-ecological conditions of central Kenya (low, medium and high altitudes). Additive main-effects, and multiplicative 
interaction (AMMI) analysis for genotype (G) and genotype $x$ environment interactions (GE) was used to identify the 26 elite lines from five market classes. The major characteristics of these lines are presented in Table 1. In addition to these elite lines, 10 parental cultivars used in population development were included as checks.

During population development, Mex54 and G10909 were used as sources of resistance to ALS; G2333 for anthracnose, RWR719 and AND1062 for root rots and BRB191 for BCMV. Commercial check varieties included GLP92 (Mwitemania), GLP585 (Wairimu), KATB9 and KATB1 which are susceptible parents but with high yield potential, marketdemanded traits and good adaptation to agroecological conditions of Eastern Africa. Major characteristics of these parental genotypes are described in Table 2.

Population development was done from 2009 using the gamete selection breeding method, as first described by Singh (1994). Development of male gametes involved making single crosses in the first round of crossing. The single crosses were subsequently combined into double crosses. Male gametes with requisite resistance genes were then identified using markers SAB-3 for anthracnose (Garzon et al., 2008); SH-13 for ALS (Mahuku et al., 2011); SW-13 for BCMV (Sharma et al., 2008) and PYAA-19 for Pythium root rot (Namayanja et al., 2014). These male gametes were, thereafter, used to construct the $F_{1}$ by the final cross of the double-cross gamete to the commercial varieties (Singh, 1994; Mondo et al., 2018). Selection also started in $F_{1}$ instead of $F_{2}$, in normal cases.

A total of 16 populations were developed. The segregating $F_{1}$ and $F_{1.2}$ populations were then evaluated for agronomic attributes, and tested for resistance to target diseases under natural disease infestation in the field at Kabete and Tigoni in 2011 and 2012 in Kenya. Molecular markers were used for screening the male gametes and the segregating $F_{1}$. From
F1.2 to F1.6 generations, bean progenies were advanced following gamete selection procedure as modified by Mondo et al. (2018). This was conducted during the period from 2013 to 2016 .

A multisite testing of $\mathrm{F}_{1.7}$ bean lines grouped in five major market classes, was conducted in 2017-2018 short rainy season in three agroecological conditions representing the low-, medium- and high-altitude environments. Lines used in this study were the $\mathrm{F}_{1.8}$ elite lines (with high yield potential) selected from that multisite evaluation.

\section{Experimental procedures}

Pathogen isolation, inoculum preparation and plant inoculation. Common bean plant parts (leaves, roots, stems or pods) infected by anthracnose, ALS, root rot, CBB and BCMV were collected from various areas in central Kenya. The collection areas were selected based on previous country-wide surveys (Omunyin et al., 1995; Mwang'ombe et al., 2007; Musyimi, 2014; Njuguna, 2014), which identified regions with the highest prevalence for each of those pathogens. These areas included Kabete (Nairobi County), Tigoni and Limuru (Kiambu County), Mwea (Kirinyaga County) and Naivasha (Nakuru County). Most of the diseased plant samples were collected during the 2017 short rainy season (from October 2017 to February 2018). Specific pathogen isolation and procedures are described below.

Anthracnose. Collectotrichum lindemuthianum was isolated from diseased bean leaves following Sicard et al. (1997) procedure. The concentration of the inoculum was adjusted to $2 \times 10^{6}$ conidia per ml using a haemocytometer for pathogens as suggested by Bigirimana and Hofte (2001). Twenty onedays-old seedlings were covered with polythene plastic bags to provide a humid environment, 12 hours before inoculation. The plants were then inoculated by spraying spore 
TABLE 1. Characteristics of 26 elite lines used in common bean multi-disease resistance validation study in controlled environments, at Kabete Field Station, Kenya

\begin{tabular}{|c|c|c|c|c|c|c|}
\hline Line & Seed colour & Growth habit & Seed size & $\begin{array}{l}{ }^{8} \text { Yield } \\
\left(\mathrm{kg} \mathrm{ha}^{-1}\right)\end{array}$ & Recommended areas & Pedigree \\
\hline KMA13-27-27 & Tan red & IV & Medium & 2,845 & Low- and highland & KATB1 x Mex54 / G2333 // AND1062 / BRB191 \\
\hline KMA13-28-5 & Tan red & IV & Medium & 1,947 & Lowland & KATB1 x Mex54 / G2333 // RWR719 / BRB191 \\
\hline KMA13-28-13 & Tan red & IV & Medium & 1,869 & Midland & KATB1 x Mex54 / G2333 // RWR719 / BRB191 \\
\hline KMA13-31-62 & Tan brown & III & Medium & 1,989 & Lowland & KATB9 x Mex54 / G2333 // AND1062 / BRB191 \\
\hline KMA13-27-12 & Black & II & Medium & 2,044 & Midland & KATB1 x Mex54 / G2333 // AND1062 / BRB191 \\
\hline KMA13-28-21 & Black & III & Medium & 3,718 & Mid- and highland & KATB1 x Mex54 / G2333 // RWR719 / BRB191 \\
\hline KMA13-21-20 & Yellow & IV & Medium & 2,329 & Mid- and highland & GLP92 x G10909 / G2333 // AND1062 / BRB191 \\
\hline KMA13-21-10 & Pinto & III & Medium & 2,285 & Lowland & GLP92 x G10909 / G2333 // AND1062 / BRB191 \\
\hline KMA13-22-21 & Pinto & III & Medium & 2,748 & Low-, mid-, highland & GLP92 x G10909 / G2333 // RWR719 / BRB191 \\
\hline KMA13-22-30 & Pinto & III & Medium & 2,726 & Highland & GLP92 x G10909 / G2333 // RWR719/ BRB191 \\
\hline KMA13-23-13 & Pinto & III & Medium & 2,031 & Midland & GLP92 x Mex54 / G2333 // AND1062 / BRB191 \\
\hline KMA13-23-22 & Pinto & III & Medium & 2,360 & Highland & GLP92 x Mex54 / G2333 // AND1062 / BRB191 \\
\hline KMA13-24-7 & Pinto & III & Medium & 2,136 & Highland & GLP92 x Mex54 / G2333 // AND1062 / BRB191 \\
\hline KMA13-26-32 & Red kidney & III & Large & 2,370 & Lowland & KATB1 x G10909 / G2333 // RWR719 / BRB191 \\
\hline KMA13-27-31 & Red kidney & III & Large & 2,136 & Lowland & KATB1 x Mex54 / G2333 // AND1062 / BRB191 \\
\hline KMA13-28-2 & Red kidney & II & Large & 2,318 & Highland & KATB1 x Mex54 / G2333 // RWR719 / BRB191 \\
\hline KMA13-30-22 & Red kidney & III & Medium & 3,226 & Mid- and highland & KATB9 x G10909 / G2333 // RWR719 / BRB191 \\
\hline KMA13-21-11 & Red kidney & II & Large & 2,448 & Midland & GLP92 x G10909 / G2333 // AND1062 / BRB191 \\
\hline KMA13-17-25 & Red mottled & I & Large & 2,038 & Midland & GLP585 x G10909 / G2333 // AND1062 / BRB191 \\
\hline KMA13-29-21 & Red mottled & II & Large & 3,860 & Low-, mid-, highland & KATB9 x G10909 / G2333 // AND1062 / BRB191 \\
\hline KMA13-29-24 & Red mottled & IV & Medium & 2,640 & Low- and highland & KATB9 x G10909 / G2333 // AND1062 / BRB191 \\
\hline KMA13-17-17 & Red mottled & II & Large & 2,525 & Midland & GLP585 x G10909 / G2333 // AND1062 / BRB191 \\
\hline KMA13-23-14 & Small red & IV & Medium & 3,022 & Low- and highland & GLP92 x Mex54 / G2333 // AND1062 / BRB191 \\
\hline KMA13-25-9 & Small red & IV & Medium & 3,385 & Low- and highland & KATB1 x G10909 / G2333 // AND1062/ BRB191 \\
\hline KMA13-30-14 & Small red & III & Medium & 2,787 & Highland & KATB9 x G10909 / G2333 // RWR719 / BRB191 \\
\hline KMA13-32-28 & Small red & III & Medium & 2,453 & Lowland & KATB9 x Mex54 / G2333 // RWR719 / BRB191 \\
\hline
\end{tabular}

${ }^{\S}$ Yield data is from a multi-environment evaluation at three locations during the 2017 short rainy season (Mondo et al., 2019a; 2019b). 
TABLE 2. Major characteristics of parental lines used for population development

\begin{tabular}{|c|c|c|c|c|c|c|c|c|c|}
\hline \multirow[t]{2}{*}{ Genotypes } & \multirow{2}{*}{$\begin{array}{l}{ }^{1} \text { Gene } \\
\text { pool }\end{array}$} & \multirow[t]{2}{*}{ Seed colour } & \multirow{2}{*}{$\begin{array}{c}{ }^{2} \text { Growth } \\
\text { habit }\end{array}$} & \multicolumn{4}{|c|}{${ }^{3}$ Reaction to diseases } & \multirow[t]{2}{*}{ Linked markers } & \multirow[t]{2}{*}{ Reference } \\
\hline & & & & ALS & ANT & $\mathrm{RR}$ & BCMV & & \\
\hline \multicolumn{10}{|c|}{ Donor parents } \\
\hline G2333 & M & Red & IV & $\mathrm{R}$ & $\mathrm{R}$ & $\mathrm{S}$ & $\mathrm{S}$ & SAB-3 & Garzón et al. (2008) \\
\hline Mex54 & M & Cream beige & IV & $\mathrm{R}$ & S & $\mathrm{S}$ & $\mathrm{S}$ & OPE $4^{708}$ & De Queiroz et al. (2004) \\
\hline G10909 & M & Red & IV & $\mathrm{R}$ & $\mathrm{S}$ & $\mathrm{S}$ & $\mathrm{S}$ & SH13 ${ }^{520}$ & Mahuku et al. (2011) \\
\hline RWR719 & M & Red & $\mathrm{I}$ & $S$ & S & $\mathrm{R}$ & $\mathrm{S}$ & PYAA19 ${ }^{800}$ & Buruchara et al. (2015) \\
\hline AND1062 & A & Red Kidney & I & $\mathrm{S}$ & $\mathrm{S}$ & $\mathrm{R}$ & $\mathrm{S}$ & PYAA19 $9^{800}$ & Namayanja et al. (2014) \\
\hline BRB191 & A & Red Mottled & I & $\mathrm{S}$ & $\mathrm{S}$ & $\mathrm{S}$ & $\mathrm{R}$ & SW13 ${ }^{690}$ & Sharma et al. (2008) \\
\hline \multicolumn{10}{|c|}{ Susceptible parents } \\
\hline GLP585 & M & Red & I & $\mathrm{S}$ & $S$ & $\mathrm{~S}$ & $S$ & N/A & \\
\hline GLP92 & M & Pinto & II & $S$ & $S$ & $S$ & $\mathrm{~S}$ & N/A & \\
\hline KATB1 & M & Green & I & $\mathrm{S}$ & $S$ & $\mathrm{~S}$ & $\mathrm{~S}$ & N/A & \\
\hline KATB9 & M & Red & I & $S$ & $S$ & $\mathrm{~S}$ & $\mathrm{~S}$ & N/A & \\
\hline
\end{tabular}

${ }^{1} \mathrm{~A}=$ Andean, $\mathrm{M}=$ Mesoamerican; ${ }^{2} \mathrm{I}=$ determinate, $\mathrm{II}$ = indeterminate bush, erect stem and branches, $\mathrm{III}=$ indeterminate bush with weak and prostrate stem and branches, IV = indeterminate climbing habit with weak, long and twisted stem and branches; ${ }^{3} \mathrm{R}=$ resistant, $\mathrm{S}=$ susceptible, ALS = angular leaf spot, $\mathrm{ANT}=$ anthracnose, $\mathrm{BCMV}=$ bean common mosaic virus, $\mathrm{RR}=$ Pythium root rot 
suspension on the leaves evenly with a handheld atomiser. After inoculation, the plants were covered with moistened polythene bags and transferred into the greenhouse.

Angular leaf spot (ALS). The Pseudocercospora griseola causing the ALS was isolated from infected leaves by transferring ALS lesions on the underside of leaves on V8 agar, using an inoculating needle; then incubated and multiplied following procedures by Correa and Saettler (1987) and Wagara et al. (1999). Spores for inoculation were obtained by gently scraping the surface of sporulating colonies incubated for 14 days in sterile distilled water. Inoculations were done on both sides of the first and second trifoliolate leaves 21 days after planting.

Root rots. Bean plants were uprooted based on the presence of root rot-like symptoms prevailing on leaves, roots and stems. Isolation procedure described by White (1988) and modified by Nzungize et al. (2011b) was used. Fusarium, Rhizoctonia and Pythium root rots were then multiplied by plating mycelia on autoclaved millet grains $(300 \mathrm{~g})$ mixed with $200 \mathrm{ml}$ of water in $1000 \mathrm{ml}$ bottles. After two weeks of incubation under darkness and at 25 ${ }^{\circ} \mathrm{C}$, a pre-sterilised soil was mixed with the infested millet at a ratio of $1: 10 \mathrm{v} / \mathrm{v}$ in polyphene pots three days before planting (Buruchara $e t$ al., 2015). Three weeks after emergence of the seedlings, the surviving plants were uprooted and washed with water to remove soil.

Bean common mosaic virus (BCMV). Young infected leaves of bean with distinct mosaic symptoms were collected and the standard inoculum obtained using the procedure by Verma and Gupta (2010). The plant inoculation was done following suggestions by Strausbaugh et al. (1999), when primary leaves were fully expanded. This corresponded with 14 days after seedling emergence.
Common bacterial blight (CBB). CBB pathogen was isolated from leaves and stems. Isolation, inoculum preparation and spraying were following procedures previously described by Harveson and Schwartz (2007). The inoculum was sprayed on plants 14 days after seedling emergence. Inoculated plants were covered with plastic bags, and placed into incubators. After four days, plants were then transferred in the greenhouse until symptom development.

\section{Experimental design and data collection.} The screening experiments for ALS, anthracnose, BCMV and CBB resistance were conducted in a greenhouse at Kabete Field Station of the University of Nairobi. Screening for resistance to Fusarium solani pv. phaseoli, Rhizoctonia solani, and Pythium ultimum root rots was conducted in an insect proof screenhouse at Kabete Field Station.

The experimental design for each trial was a randomised complete block design (RCBD), with four replications. Treatments consisted of 36 genotypes including 26 elite bean lines and 10 parents used as check varieties. A separate, but similar experiment was set for each disease in which treatments were clearly labeled and randomly arranged within the greenhouse. Each plot consisted of four pots, each containing four plants making a total of 16 plants for each genotype in a replication.

Pots were uniformly filled with presterilised soils, mixed with cattle manure in compost form, and sand at a ratio of 3:1:1. As described previously in the study site section, Kabete' soils used for this experiment are well drained, very deep, dark reddish brown, friable clay with acid humic topsoil, humic nitisols and a $\mathrm{pH}$ ranging from 5.0 to 5.4.

Diammonium phosphate (DAP) (N 18\%: $\left.\mathrm{P}_{2} \mathrm{O}_{5} 46 \%\right)$ at a rate of $80 \mathrm{~kg} \mathrm{ha}^{-1}(12.8 \mathrm{~g}$ per pot) was applied at planting, in each pot. The pots were irrigated to field capacity to ensure moisture-free conditions for the study plants, except the root rot experiments which relied exclusively on rain for water. Rainfall 
distribution during the study period was favourable for disease development in the insect-proof screenhouse; as mean monthly rainfall was approximately $275.7 \mathrm{~mm}$ from March to June 2018; while the mean temperature was $18.2{ }^{\circ} \mathrm{C}$.

Data on disease incidence and severity were recorded at seven day intervals $(14,21$ and 28 days) after inoculation for ALS, BCMV, anthracnose and $\mathrm{CBB}$. Data on root rots were taken once, 21 days after seedling emergence. The disease severity was rated using a 1-9 CIAT scale: 1-3 being resistant, 3.1-6 intermediate and 6.1-9 susceptible (Schoonhoven and Pastor-Corrales, 1987; Okii et al., 2017). The disease incidence was the percentage of diseased plants from the total number of plants initially inoculated.

Data analysis. GenStat $15^{\text {th }}$ edition software (VSN Int., 2013) was used for analysis of variance. Fisher's protected least significant difference (LSD) was used for mean separation at 1 and 5 percent probability levels. Area under disease progression curve (AUDPC) was performed for each genotype using the midpoint rule method (Campbell and Madden, 1990) as follows:

$$
\mathrm{AUDPC}=\sum_{i=1}^{n-1}\left(\frac{y_{i}+y_{i+1}}{2}\right)\left(t_{i+1}-t_{i}\right)
$$

Where:

$t$ represents the time in days of each observation, $y$ is disease severity at observation and, $n$ is the number of observations.

The AUDPCs were then subjected to ANOVA to compare amounts of disease among different bean lines for each disease pathogen. The highest values corresponded to more susceptible; while the lowest values corresponded to more resistant varieties.

\section{RESULTS}

Disease severity and AUDPC. Disease severity score showed no significant $(\mathrm{P}>0.05)$ differences in the elite lines and check varieties to the three root rot pathogens (Table 3). However, genotypes reacted differently to ALS $(\mathrm{P}<0.05), \mathrm{BCMV}(\mathrm{P}<0.01), \mathrm{CBB}(\mathrm{P}<0.01)$ and anthracnose pathogen $(\mathrm{P}<0.001)$. The differences among genotypes were even highly significant $(\mathrm{P}<0.001)$ when referring to computed AUDPC values, regardless of the pathogens (Table 4).

Reaction to root rot diseases. Figure 1 presents symptoms of the three root rot pathogens as observed on susceptible genotypes during the screenhouse testing at Kabete, University of Nairobi. The Fusarium root rot was the most damaging on the tested materials; its incidence ranged from $43.3 \%$ on KMA13-27-31 to $96.1 \%$ on the check variety BRB191 (Table 5). Disease severity was also high, ranging from 2.8 on KMA13-27-31 to 6.9 on KMA13-17-25. KMA13-27-31, a red kidney genotype, was the only elite line which showed resistance to Fusarium root rot. Rhizoctonia root rot affected more than $50 \%$ of plants for all the genotypes, but the severity was very low (1.5 to 5.0 ).

The Pythium root rot incidence was also very high, ranging from 53.9 to $84.6 \%$ (Table 5). Severity of Pythium root rot varied from 2.1 on KMA13-32-28 to 5.8 on the check variety KATB1. None of the elite lines or check varieties combined concurrently, resistance to the three root rot-causing agents. However, 6 elite lines (KMA13-21-11; KMA13-23-14; KMA13-25-9; KMA13-28-5; KMA13-30-14 and KMA13-32-28) had combined resistance to Rhizoctonia and Pythium root rots; while KMA13-27-31 had concurrent resistance to Fusarium and Rhizoctonia root rots. Fortunately, more than $80 \%$ (21 of the 26) of 
TABLE 3. Mean squares of incidence and severity scores for the foliar pathogens on elite bean lines at the final score (28 days after inoculation) in a $ॄ$ greenhouse at Kabete, University of Nairobi, Kenya

\begin{tabular}{|c|c|c|c|c|c|c|c|c|c|}
\hline \multirow[t]{2}{*}{ Sources of variation } & \multirow[t]{2}{*}{ DF } & \multicolumn{2}{|c|}{ ALS } & \multicolumn{2}{|c|}{ BCMV } & \multicolumn{2}{|c|}{ CBB } & \multicolumn{2}{|c|}{ ANTH } \\
\hline & & Incidence & Severity & Incidence & Severity & Incidence & Severity & Incidence & Severity \\
\hline Replication & 3 & 5605.6 & 62.3 & 2322.2 & 6.1 & 4170.9 & 100.3 & 5.6 & 13.3 \\
\hline Genotype & 35 & $712.4^{\mathrm{ns}}$ & $1.7 *$ & $1504.9^{\text {ns }}$ & $3.1 * *$ & $1235.2 * * *$ & $3.4 * *$ & $952.1 * * *$ & $2.8^{\mathrm{ns}}$ \\
\hline Residual & 35 & 493.5 & 0.78 & 864.6 & 0.92 & 173.0 & 1.0 & 2.1 & 2.4 \\
\hline Total & 73 & & & & & & & & \\
\hline Mean & & 28.7 & 2.7 & 75.1 & 3.5 & 50.9 & 3.6 & 28.9 & 2.6 \\
\hline $\mathrm{LSD}_{0.05}$ & & 45.1 & 1.8 & 59.7 & 1.9 & 26.7 & 2.0 & 2.9 & 59.1 \\
\hline $\mathrm{CV}(\%)$ & & 77.5 & 32.9 & 39.2 & 27.8 & 25.9 & 27.5 & 5.0 & 52.1 \\
\hline
\end{tabular}


TABLE 4. Mean squares of AUDPC for the foliar pathogens on inter-racial elite common bean lines grown in a greenhouse at Kabete, University of Nairobi, Kenya

\begin{tabular}{|c|c|c|c|c|c|c|c|c|c|}
\hline \multirow[t]{2}{*}{ Sources of variation } & \multirow[t]{2}{*}{ DF } & \multicolumn{2}{|c|}{ ALS } & \multicolumn{2}{|c|}{ BCMV } & \multicolumn{2}{|c|}{$\mathrm{CBB}$} & \multicolumn{2}{|c|}{ ANTH } \\
\hline & & Incidence & Severity & Incidence & Severity & Incidence & Severity & Incidence & Severity \\
\hline Replication & 3 & 17564. & 741.1 & 122896. & 115.0 & 158109. & 5270.2 & 345 & 1378.1 \\
\hline Genotype & 35 & $81206 . * * *$ & $78.8 * * *$ & $133628 . * * *$ & $364.9 * * *$ & 207554 .*** & $418.4 * * *$ & $195616^{* * *}$ & $337.6^{\mathrm{ns}}$ \\
\hline Residual & 35 & 8782. & 16.6 & 21915. & 18.8 & 20882. & 74.5 & 153 & 274.6 \\
\hline Total & 73 & & & & & & & & \\
\hline Mean & & 486.5 & 32.2 & 1002 & 41.7 & 614.7 & 42.8 & 342.7 & 31.8 \\
\hline $\mathrm{LSD}_{0.05}$ & & 190.2 & 8.3 & 300.5 & 8.8 & 293.4 & 17.5 & 25.1 & 33.6 \\
\hline $\mathrm{CV}(\%)$ & & 19.3 & 12.7 & 14.8 & 10.4 & 23.5 & 20.2 & 3.6 & 52.1 \\
\hline
\end{tabular}

$\mathrm{DF}=$ degree of freedom, $\mathrm{LSD}_{0.5}=$ least significant difference at $5 \% \mathrm{P}$-value threshold, $\mathrm{CV}=$ coefficient of variation, $\mathrm{ns}=$ not significant, $* * *=$ significan at $\mathrm{P}=0.001$. ALS $=$ angular leaf spot, $\mathrm{BCMV}=$ bean common mosaic virus, $\mathrm{CBB}=$ common bacterial blight, $\mathrm{ANTH}=$ anthracnose 


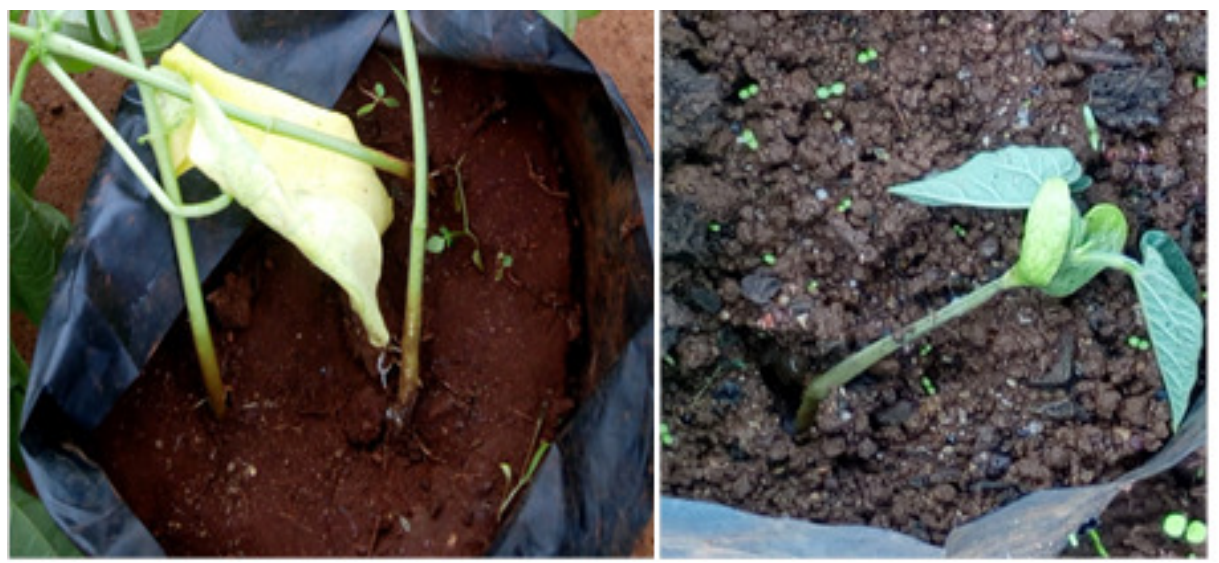

Pythium root rot

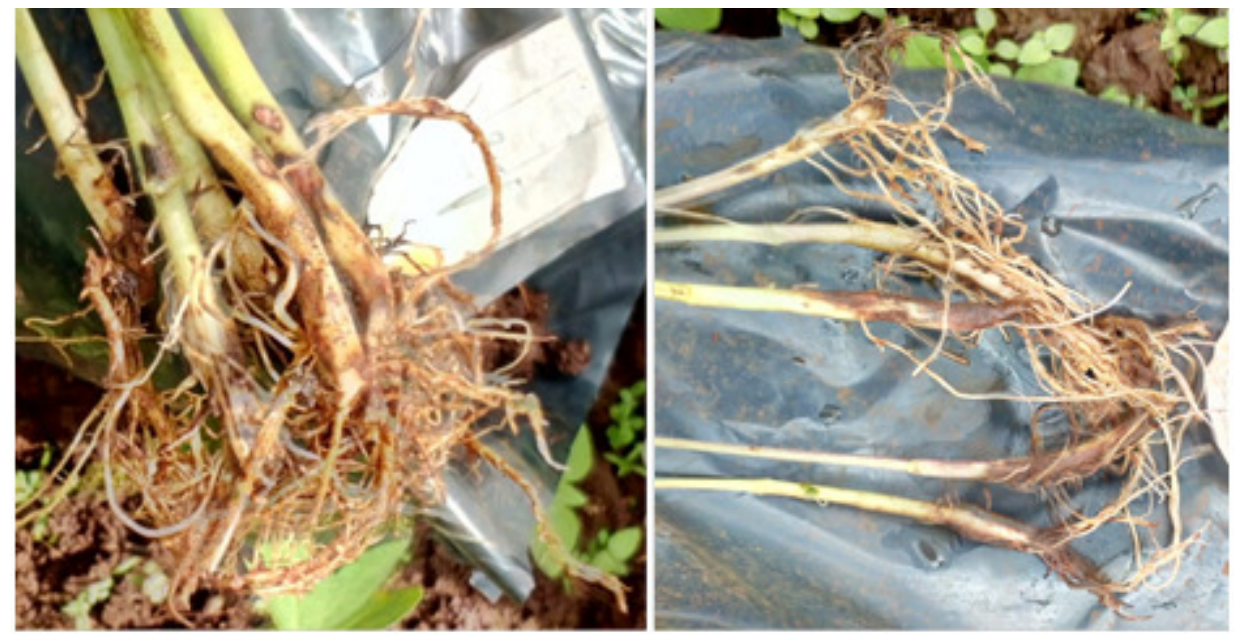

Fusarium root rot

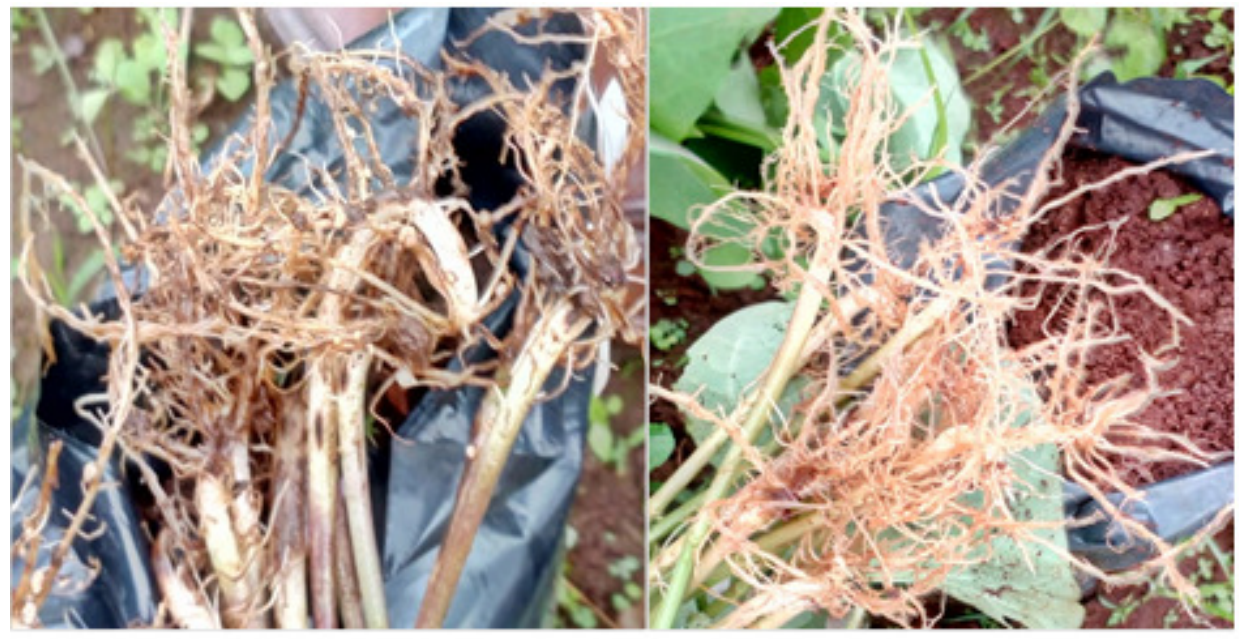

Rhizoctonia root rot

Figure 1. Root rot symptoms on susceptible inter-racial elite common bean lines grown in a greenhouse at Kabete, University of Nairobi, Kenya. 
TABLE 5. Incidence and severity of Fusarium, Rhizoctonia and Pythium root rots on inter-racial elite common bean lines grown in a greenhouse at Kabete, University of Nairobi, Kenya

\begin{tabular}{|c|c|c|c|c|c|c|c|c|c|}
\hline \multirow[t]{2}{*}{ Genotype } & \multicolumn{3}{|c|}{ Fusarium } & \multicolumn{3}{|c|}{ Rhizoctonia } & \multicolumn{3}{|c|}{ Pythium } \\
\hline & $\begin{array}{c}\text { Incidence } \\
(\%)\end{array}$ & Severity & $\mathrm{RC}$ & $\begin{array}{l}\text { Incidence } \\
(\%)\end{array}$ & Severity & $\mathrm{RC}$ & $\begin{array}{c}\text { Incidence } \\
(\%)\end{array}$ & Severity & $\mathrm{RC}$ \\
\hline KMA13-17-17 & 69.3 & 4.2 & I & 53.9 & 2.0 & $\mathrm{R}$ & 69.3 & 3.6 & I \\
\hline KMA13-17-25 & 92.3 & 6.9 & $\mathrm{~S}$ & 50.0 & 1.5 & $\mathrm{R}$ & 84.6 & 4.4 & I \\
\hline KMA13-21-10 & 73.1 & 3.9 & I & 53.9 & 3.0 & $\mathrm{R}$ & 65.4 & 3.6 & $\mathrm{I}$ \\
\hline KMA13-21-11 & 65.4 & 6.1 & $\mathrm{~S}$ & 50.0 & 1.5 & $\mathrm{R}$ & 61.6 & 2.9 & $\mathrm{R}$ \\
\hline KMA13-21-20 & 73.1 & 4.9 & I & 53.9 & 4.2 & I & 65.4 & 3.4 & $\mathrm{I}$ \\
\hline KMA13-22-21 & 73.1 & 4.7 & I & 53.9 & 4.0 & I & 53.9 & 2.3 & $\mathrm{R}$ \\
\hline KMA13-22-30 & 76.9 & 5.4 & I & 53.9 & 3.2 & I & 73.1 & 4.4 & $\mathrm{I}$ \\
\hline KMA13-23-13 & 69.3 & 4.1 & I & 53.9 & 2.3 & $\mathrm{R}$ & 69.3 & 3.6 & I \\
\hline KMA13-23-14 & 73.1 & 5.2 & I & 53.9 & 3.0 & $\mathrm{R}$ & 61.6 & 2.9 & $\mathrm{R}$ \\
\hline KMA13-23-22 & 84.6 & 6.2 & I & 57.7 & 2.1 & $\mathrm{R}$ & 61.6 & 3.3 & $\mathrm{I}$ \\
\hline KMA13-24-7 & 61.6 & 3.8 & I & 50.0 & 1.5 & $\mathrm{R}$ & 57.7 & 3.1 & I \\
\hline KMA13-25-9 & 65.4 & 4.6 & I & 53.9 & 2.5 & $\mathrm{R}$ & 53.9 & 2.5 & $\mathrm{R}$ \\
\hline KMA13-26-32 & 69.3 & 5.0 & I & 53.9 & 1.8 & $\mathrm{R}$ & 69.3 & 3.9 & $\mathrm{I}$ \\
\hline KMA13-27-12 & 84.6 & 5.9 & I & 57.7 & 3.1 & I & 69.3 & 4.5 & $\mathrm{I}$ \\
\hline KMA13-27-27 & 80.8 & 5.5 & I & 50.0 & 1.5 & $\mathrm{R}$ & 59.1 & 3.9 & I \\
\hline KMA13-27-31 & 49.3 & 2.8 & $\mathrm{R}$ & 50.0 & 1.5 & $\mathrm{R}$ & 57.7 & 3.9 & I \\
\hline KMA13-28-13 & 80.8 & 6.5 & $\mathrm{~S}$ & 53.9 & 2.0 & $\mathrm{R}$ & 65.4 & 3.3 & I \\
\hline KMA13-28-2 & 61.6 & 4.1 & I & 50.0 & 1.5 & $\mathrm{R}$ & 57.7 & 3.9 & $\mathrm{I}$ \\
\hline KMA13-28-21 & 65.4 & 3.4 & I & 53.9 & 5.0 & I & 53.9 & 2.8 & $\mathrm{R}$ \\
\hline KMA13-28-5 & 80.8 & 6.0 & I & 53.9 & 3.0 & $\mathrm{R}$ & 59.1 & 2.6 & $\mathrm{R}$ \\
\hline KMA13-29-21 & 69.3 & 5.0 & I & 53.9 & 2.0 & $\mathrm{R}$ & 73.1 & 4.4 & $\mathrm{I}$ \\
\hline KMA13-29-24 & 76.9 & 4.9 & $\mathrm{I}$ & 50.0 & 1.5 & $\mathrm{R}$ & 61.6 & 3.4 & $\mathrm{I}$ \\
\hline KMA13-30-14 & 88.5 & 5.9 & $\mathrm{I}$ & 53.9 & 3.0 & $\mathrm{R}$ & 53.9 & 2.5 & $\mathrm{R}$ \\
\hline KMA13-30-22 & 80.8 & 5.6 & I & 53.9 & 1.8 & $\mathrm{R}$ & 84.6 & 5.6 & $\mathrm{I}$ \\
\hline KMA13-31-62 & 73.1 & 4.9 & I & 61.6 & 3.7 & $\mathrm{I}$ & 65.4 & 4.1 & $\mathrm{I}$ \\
\hline KMA13-32-28 & 61.6 & 4.9 & $\mathrm{I}$ & 53.9 & 2.0 & $\mathrm{R}$ & 57.7 & 2.1 & $\mathrm{R}$ \\
\hline AND1062 & 69.3 & 4.4 & I & 50.0 & 1.5 & $\mathrm{R}$ & 73.1 & 3.6 & I \\
\hline BRB191 & 96.2 & 6.5 & $\mathrm{~S}$ & 53.9 & 1.8 & $\mathrm{R}$ & 80.8 & 4.9 & $\mathrm{I}$ \\
\hline G10909 & 80.8 & 6.1 & $\mathrm{~S}$ & 57.7 & 2.1 & $\mathrm{R}$ & 69.3 & 3.4 & $\mathrm{I}$ \\
\hline G2333 & 57.7 & 3.9 & I & 50.0 & 1.5 & $\mathrm{R}$ & 53.9 & 2.3 & $\mathrm{R}$ \\
\hline GLP585 & 61.6 & 2.9 & $\mathrm{R}$ & 50.0 & 1.5 & $\mathrm{R}$ & 69.3 & 3.6 & I \\
\hline GLP92 & 92.3 & 5.9 & I & 50.0 & 1.5 & $\mathrm{R}$ & 69.3 & 3.9 & $\mathrm{I}$ \\
\hline KATB1 & 69.3 & 3.9 & I & 53.9 & 2.3 & $\mathrm{R}$ & 80.8 & 5.8 & $\mathrm{I}$ \\
\hline KATB9 & 80.8 & 5.9 & I & 50.0 & 1.5 & $\mathrm{R}$ & 57.7 & 3.0 & $\mathrm{R}$ \\
\hline Mex54 & 88.5 & 6.1 & $\mathrm{~S}$ & 50.0 & 1.5 & $\mathrm{R}$ & 61.6 & 2.4 & $\mathrm{R}$ \\
\hline RWR719 & 76.9 & 4.2 & I & 50.0 & 1.5 & $\mathrm{R}$ & 57.7 & 2.6 & $\mathrm{R}$ \\
\hline $\mathrm{LSD}_{0.05}$ & 29.1 & 2.7 & & 8.1 & 2.0 & & 25.0 & 1.9 & \\
\hline $\mathrm{CV}(\%)$ & 19.3 & 26.4 & & 7.5 & 45.1 & & 18.9 & 27.9 & \\
\hline
\end{tabular}

$\mathrm{RC}=$ reaction category; $\mathrm{R}=$ resistant $\mathrm{I}=$ intermediate; $\mathrm{S}=$ susceptible; $\mathrm{LSD}=$ least significant difference at $\mathrm{P}$-value threshold of $0.05 ; \mathrm{CV}=$ coefficient of variation 
the elite lines combined moderate resistance (scores of 4 to 6 ) for reaction to the three root rots.

Bean common mosaic virus (BCMV). Field illustration of the BCMV disease progression is presented in Figure 2 for the 14, 21 and 28 days after inoculation. A total of 13 elite lines were resistant to $\mathrm{BCMV}$; while the other 13 were moderately resistant (Table 6). However, none of the elite lines was completely immune or highly susceptible to BCMV. Four of the 10 checks were resistant, five were intermediate and one (KATB1) was highly susceptible. The $\mathrm{BCMV}$ incidence was very high and increased over time from 34.8 percent 14 days after inoculation, to 88.2 percent after 21 days and to 93.4 percent on the $28^{\text {th }}$ day after inoculation.

The disease severity score increased from 2.5 on the $14^{\text {th }}$ day after inoculation, to 3.0 and 3.5 on the $21^{\text {st }}$ and $28^{\text {th }}$ days after inoculation, respectively. There were highly significant differences $(\mathrm{P}<0.001)$ among genotypes for their reaction to $\mathrm{BCMV}$ for severity AUDPCs. The highest levels of infection were recorded on the check variety KATB1 (82.2). Line KMA13-30-14 (24.5) was the most resistant genotype among all the elite lines and checks. Other elite lines with low
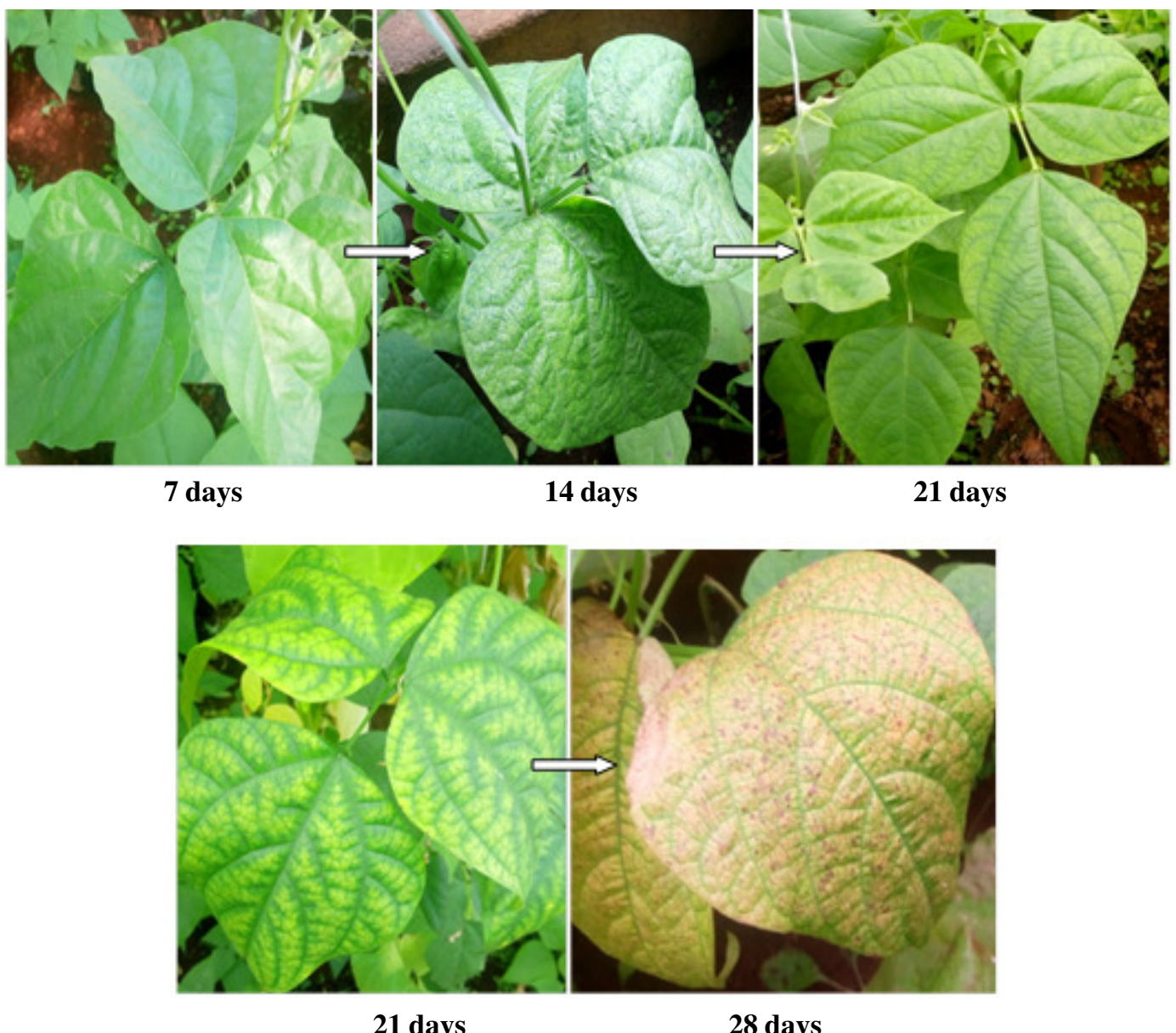

Figure 2. Bean common mosaic virus disease progression on susceptible cultivar (KATB1) used as check in a greenhouse at Kabete, University of Nairobi, Kenya. Days = days after plant inoculation. 
TABLE 6. Incidence and severity of bean common mosaic virus on inter-racial elite common bean lines grown in a greenhouse at Kabete, University of Nairobi, Kenya

\begin{tabular}{|c|c|c|c|c|c|c|c|c|}
\hline \multirow[t]{2}{*}{ Genotype } & \multicolumn{2}{|c|}{$\begin{array}{l}14 \text { days } \\
\text { after inoculation }\end{array}$} & \multicolumn{2}{|c|}{$\begin{array}{c}21 \text { days } \\
\text { after inoculation }\end{array}$} & \multicolumn{2}{|c|}{$\begin{array}{l}28 \text { days } \\
\text { after inoculation }\end{array}$} & \multirow[t]{2}{*}{$\begin{array}{l}\text { Severity } \\
\text { AUDPC }\end{array}$} & \multirow[t]{2}{*}{$\mathrm{RC}$} \\
\hline & $\begin{array}{l}\text { Incidence } \\
(\%)\end{array}$ & Severity & $\begin{array}{l}\text { Incidence } \\
(\%)\end{array}$ & Severity & $\begin{array}{l}\text { Incidence } \\
(\%)\end{array}$ & Severity & & \\
\hline KMA13-17-17 & 16.7 & 1.5 & 100.0 & 3.0 & 100.0 & 4.5 & 42.0 & I \\
\hline KMA13-17-25 & 50.0 & 2.0 & 100.0 & 2.0 & 100.0 & 4.0 & 35.0 & I \\
\hline KMA13-21-10 & 16.7 & 2.0 & 66.6 & 4.0 & 80.0 & 5.5 & 54.2 & I \\
\hline KMA13-21-11 & 35.0 & 4.0 & 94.5 & 4.0 & 100.0 & 4.5 & 57.8 & I \\
\hline KMA13-21-20 & 25.0 & 2.0 & 100.0 & 3.0 & 100.0 & 4.0 & 42.0 & I \\
\hline KMA13-22-21 & 8.4 & 1.5 & 33.3 & 2.0 & 58.4 & 2.0 & 26.2 & $\mathrm{R}$ \\
\hline KMA13-22-30 & 35.0 & 3.0 & 33.3 & 4.0 & 80.0 & 3.5 & 50.8 & I \\
\hline KMA13-23-13 & 41.7 & 3.5 & 91.7 & 3.0 & 98.4 & 2.5 & 42.0 & $\mathrm{R}$ \\
\hline KMA13-23-14 & 28.6 & 2.0 & 100.0 & 3.0 & 100.0 & 3.5 & 40.2 & I \\
\hline KMA13-23-22 & 50.0 & 1.5 & 100.0 & 2.0 & 100.0 & 2.0 & 26.2 & $\mathrm{R}$ \\
\hline KMA13-24-7 & 21.7 & 2.5 & 100.0 & 3.0 & 100.0 & 4.0 & 43.8 & I \\
\hline KMA13-25-9 & 43.8 & 2.0 & 100.0 & 2.0 & 100.0 & 2.5 & 29.8 & $\mathrm{R}$ \\
\hline KMA13-26-32 & 54.6 & 3.0 & 100.0 & 3.0 & 100.0 & 4.0 & 45.5 & I \\
\hline KMA13-27-12 & 8.4 & 1.5 & 100.0 & 2.0 & 100.0 & 2.0 & 26.2 & $\mathrm{R}$ \\
\hline KMA13-27-27 & 16.7 & 1.5 & 40.0 & 2.0 & 55.0 & 2.5 & 28.0 & $\mathrm{R}$ \\
\hline KMA13-27-31 & 50.0 & 2.5 & 100.0 & 2.0 & 100.0 & 4.5 & 38.5 & I \\
\hline KMA13-28-13 & 31.3 & 3.0 & 37.5 & 3.0 & 68.8 & 2.5 & 40.2 & $\mathrm{R}$ \\
\hline KMA13-28-2 & 28.6 & 4.5 & 100.0 & 5.5 & 100.0 & 5.5 & 73.5 & I \\
\hline KMA13-28-21 & 10.0 & 1.5 & 100.0 & 2.0 & 100.0 & 2.0 & 26.2 & $\mathrm{R}$ \\
\hline KMA13-28-5 & 54.8 & 3.5 & 28.6 & 2.0 & 56.0 & 3.0 & 36.8 & $\mathrm{R}$ \\
\hline KMA13-29-21 & 50.0 & 1.5 & 100.0 & 3.0 & 100.0 & 2.5 & 35.0 & $\mathrm{R}$ \\
\hline KMA13-29-24 & 16.7 & 1.5 & 100.0 & 2.0 & 100.0 & 3.0 & 29.8 & $\mathrm{R}$ \\
\hline KMA13-30-14 & 12.5 & 1.5 & 87.5 & 2.0 & 90.0 & 1.5 & 24.5 & $\mathrm{R}$ \\
\hline KMA13-30-22 & 12.5 & 1.5 & 75.0 & 3.0 & 82.5 & 3.5 & 38.5 & I \\
\hline KMA13-31-62 & 20.6 & 2.5 & 87.5 & 4.0 & 94.3 & 3.0 & 47.2 & $\mathrm{R}$ \\
\hline KMA13-32-28 & 57.5 & 3.5 & 100.0 & 5.0 & 100.0 & 4.5 & 63.0 & I \\
\hline AND1062 & 50.0 & 4.0 & 100.0 & 4.0 & 100.0 & 5.5 & 61.2 & I \\
\hline BRB191 & 47.9 & 4.0 & 100.0 & 4.0 & 100.0 & 3.5 & 40.2 & I \\
\hline G10909 & 87.5 & 4.0 & 100.0 & 3.0 & 100.0 & 2.5 & 43.8 & $\mathrm{R}$ \\
\hline G2333 & 14.3 & 1.5 & 100.0 & 2.0 & 100.0 & 3.0 & 29.8 & $\mathrm{R}$ \\
\hline GLP585 & 8.4 & 1.5 & 100.0 & 2.0 & 100.0 & 2.0 & 26.2 & $\mathrm{R}$ \\
\hline GLP92 & 18.4 & 2.0 & 100.0 & 3.0 & 100.0 & 2.5 & 36.8 & $\mathrm{R}$ \\
\hline KATB1 & 90.0 & 4.5 & 100.0 & 6.0 & 100.0 & 7.0 & 82.2 & $\mathrm{~S}$ \\
\hline КАТВ9 & 25.0 & 2.0 & 100.0 & 3.0 & 100.0 & 4.5 & 43.8 & I \\
\hline Mex54 & 50.0 & 2.5 & 100.0 & 4.0 & 100.0 & 3.5 & 49.0 & I \\
\hline RWR719 & 66.7 & 3.0 & 100.0 & 3.0 & 100.0 & 4.0 & 45.5 & I \\
\hline $\mathrm{LSD}_{0.05}$ & 22.1 & 1.8 & 13.8 & 1.2 & 29.7 & 1.9 & 8.8 & \\
\hline $\mathrm{CV}(\%)$ & 37.9 & 34.9 & 17.7 & 13.9 & 19.2 & 27.8 & 10.4 & \\
\hline
\end{tabular}

$\mathrm{RC}=$ reaction category; $\mathrm{R}=$ resistant $\mathrm{I}=$ intermediate; $\mathrm{S}=$ susceptible; $\mathrm{LSD}=$ least significant difference at $\mathrm{P}$-value threshold of $0.05 ; \mathrm{CV}=$ coefficient of variation 
levels of infection were KMA13-22-21, KMA13-23-22, KMA13-27-12, and KMA1328-21 with an AUDPC value of 26.2.

Angular leaf spot (ALS). The ALS disease progression on a susceptible genotype at the 14,21 and 28 days after inoculation is illustrated in Figure 3. Table 7 shows that 18 of the 26 elite lines were resistant to infection by ALS (Pseudocercospora griseola); eight were intermediate, and none was highly susceptible. The pathogen effects were almost static (stable) over time as the severity scores were 2.0, 2.5 and 2.8 at 14, 21 and 28 days after inoculation, respectively. However, disease incidence increased from $35.1 \%$ on the $14^{\text {th }}$ day after inoculation to $45.7 \%$ on the $21^{\text {st }}$ day, and to $51.5 \%$ on the $28^{\text {th }}$ day.

Computed AUDPCs showed that there were highly significant $(\mathrm{P}<0.001)$ differences among the genotypes for reaction to the ALS infections. The elite line KMA13-17-25, with an AUDPC value of 14.0, was the most resistant genotype to ALS compared to all other lines and parental checks. Other elite lines with low levels of infection were KMA13-27-12 (24.5), KMA13-17-17, KMA13-23-14, KMA13-26-32, and KMA13-28-21, all with an AUDPC value of 26.2.

Common bacterial blight (CBB). Table 8 shows that six of 26 elite lines were resistant to $\mathrm{CBB}$, among which KMA13-17-17,
KMA13-28-2, KMA13-28-21 and KMA13-3014 were completely immune, since not a single plant showed CBB symptoms. Eighteen of the 26 elite lines had moderate resistance (3.1 to 6.0); while two were highly susceptible (6.1 to 9). None of the check varieties was resistant to $\mathrm{CBB}$; yet eight were moderately resistant; while two were highly susceptible (Mex54 and G2333).

The CBB severity and incidence on tested lines increased over time (Fig. 4). There were highly significant $(\mathrm{P}<0.001)$ differences among genotypes for reactions to $\mathrm{CBB}$, compared to their severity AUDPCs. Based on computed AUDPC values, check variety Mex54 was the most susceptible. The lowest infection level was recorded on elite lines KMA13-17-17, KMA13-28-2 and KMA13-3014.

Anthracnose pathogen. Figure 5 illustrates the disease progression on the susceptible check KATB1 using photos. The elite lines were resistant to anthracnose (Table 9). The disease severity ranged from 1.0 on elite lines KMA13-21-20, KMA13-28-21, and KMA1329-21 to 6.0 on the check variety KATB1. Disease incidences were also low; averages were 20.9, 24.1, and 28.9\% at 14, 21 and 28 days after inoculation. As for AUDPC values, KMA13-21-20, KMA13-28-21, and KMA1329-21 were the most resistant; having recorded the lowest infection levels. The

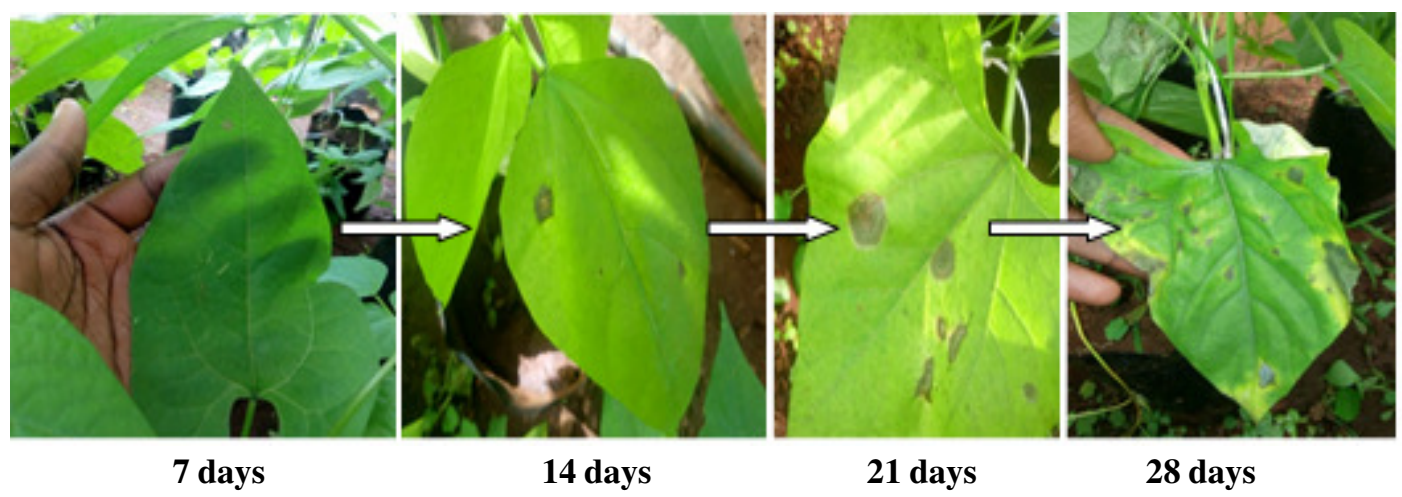

Figure 3. ALS disease progression on susceptible cultivar (RWR719) used as check in a greenhouse at Kabete, University of Nairobi, Kenya. 
TABLE 7. Incidence and severity of angular leaf spot on inter-racial elite common bean lines grown in a greenhouse at Kabete, University of Nairobi, Kenya

\begin{tabular}{|c|c|c|c|c|c|c|c|c|}
\hline \multirow[t]{2}{*}{ Genotype } & \multicolumn{2}{|c|}{$\begin{array}{l}14 \text { days } \\
\text { after inoculation }\end{array}$} & \multicolumn{2}{|c|}{$\begin{array}{l}21 \text { days } \\
\text { after inoculation }\end{array}$} & \multicolumn{2}{|c|}{$\begin{array}{l}28 \text { days } \\
\text { afterinoculation }\end{array}$} & \multirow[t]{2}{*}{$\begin{array}{l}\text { Severity } \\
\text { AUDPC }\end{array}$} & \multirow[t]{2}{*}{$\mathrm{RC}$} \\
\hline & $\begin{array}{l}\text { Incidence } \\
(\%)\end{array}$ & Severity & $\begin{array}{l}\text { Incidence } \\
\qquad(\%)\end{array}$ & Severity & $\begin{array}{l}\text { Incidence } \\
(\%)\end{array}$ & Severity & & \\
\hline KMA13-17-17 & 33.4 & 2.0 & 36.7 & 2.0 & 36.7 & 1.5 & 26.2 & $\mathrm{R}$ \\
\hline KMA13-17-25 & 0.0 & 1.0 & 0.0 & 1.0 & 0.0 & 1.0 & 14.0 & $\mathrm{R}$ \\
\hline KMA13-21-10 & 56.3 & 2.0 & 62.9 & 2.5 & 69.3 & 4.0 & 36.7 & I \\
\hline KMA13-21-11 & 38.1 & 2.0 & 38.6 & 4.0 & 50.0 & 3.5 & 40.2 & I \\
\hline KMA13-21-20 & 42.9 & 2.0 & 50.0 & 3.0 & 56.8 & 3.0 & 35.0 & $\mathrm{R}$ \\
\hline KMA13-22-21 & 59.1 & 3.0 & 64.4 & 3.5 & 68.9 & 4.5 & 49.0 & I \\
\hline KMA13-22-30 & 22.8 & 2.0 & 28.1 & 2.0 & 59.1 & 4.5 & 36.8 & I \\
\hline KMA13-23-13 & 87.5 & 2.0 & 95.0 & 3.5 & 97.5 & 4.5 & 42.0 & I \\
\hline KMA13-23-14 & 10.0 & 2.0 & 20.0 & 1.5 & 20.0 & 2.0 & 26.2 & $\mathrm{R}$ \\
\hline KMA13-23-22 & 64.3 & 2.0 & 72.9 & 4.0 & 72.9 & 4.0 & 42.0 & I \\
\hline KMA13-24-7 & 83.4 & 2.0 & 83.4 & 3.0 & 90.8 & 3.0 & 35.0 & $\mathrm{R}$ \\
\hline KMA13-25-9 & 53.6 & 2.0 & 62.2 & 3.5 & 68.6 & 3.0 & 36.8 & $\mathrm{R}$ \\
\hline KMA13-26-32 & 25.0 & 2.0 & 33.3 & 2.0 & 36.7 & 1.5 & 26.2 & $\mathrm{R}$ \\
\hline KMA13-27-12 & 0.0 & 2.0 & 33.3 & 1.0 & 38.4 & 2.0 & 24.5 & $\mathrm{R}$ \\
\hline KMA13-27-27 & 32.5 & 2.0 & 37.5 & 2.0 & 40.0 & 2.5 & 29.8 & $\mathrm{R}$ \\
\hline KMA13-27-31 & 37.5 & 2.0 & 37.5 & 2.5 & 38.8 & 2.5 & 31.5 & $\mathrm{R}$ \\
\hline KMA13-28-13 & 33.3 & 2.0 & 44.4 & 2.0 & 52.2 & 3.0 & 31.5 & $\mathrm{R}$ \\
\hline KMA13-28-2 & 42.9 & 2.0 & 42.8 & 2.0 & 55.7 & 2.5 & 29.8 & $\mathrm{R}$ \\
\hline KMA13-28-21 & 8.4 & 2.0 & 42.9 & 1.5 & 44.3 & 2.0 & 26.2 & $\mathrm{R}$ \\
\hline KMA13-28-5 & 30.3 & 2.0 & 33.3 & 2.0 & 37.5 & 2.5 & 29.8 & $\mathrm{R}$ \\
\hline KMA13-29-21 & 12.5 & 2.0 & 25.0 & 1.5 & 32.5 & 2.5 & 28.0 & $\mathrm{R}$ \\
\hline KMA13-29-24 & 18.8 & 2.0 & 25.0 & 2.0 & 28.6 & 3.5 & 33.2 & I \\
\hline KMA13-30-14 & 28.4 & 2.0 & 33.3 & 3.5 & 50.0 & 3.5 & 38.5 & I \\
\hline KMA13-30-22 & 20.0 & 2.0 & 40.0 & 2.0 & 46.7 & 2.0 & 28.0 & $\mathrm{R}$ \\
\hline KMA13-31-62 & 44.3 & 2.0 & 46.4 & 3.0 & 51.6 & 2.0 & 31.5 & $\mathrm{R}$ \\
\hline KMA13-32-28 & 12.5 & 2.0 & 25.0 & 1.5 & 33.6 & 2.5 & 28.0 & $\mathrm{R}$ \\
\hline AND1062 & 37.5 & 2.0 & 40.0 & 2.0 & 45.0 & 3.5 & 29.8 & I \\
\hline BRB191 & 62.5 & 2.0 & 70.0 & 2.5 & 77.5 & 3.0 & 29.8 & $\mathrm{R}$ \\
\hline G10909 & 63.1 & 2.0 & 67.1 & 2.0 & 68.6 & 2.0 & 38.5 & $\mathrm{R}$ \\
\hline G2333 & 25.0 & 2.0 & 50.0 & 2.0 & 56.7 & 3.5 & 29.8 & I \\
\hline GLP585 & 43.8 & 2.0 & 47.5 & 3.5 & 48.8 & 3.5 & 35.0 & I \\
\hline GLP92 & 0.0 & 3.0 & 50.0 & 1.0 & 50.0 & 4.0 & 28.0 & I \\
\hline KATB1 & 41.7 & 2.0 & 66.6 & 3.0 & 70.0 & 3.5 & 33.2 & I \\
\hline KATB9 & 26.8 & 2.0 & 35.0 & 2.5 & 42.5 & 3.5 & 28.0 & I \\
\hline Mex54 & 50.0 & 2.0 & 60.0 & 2.0 & 65.0 & 2.2 & 35.0 & $\mathrm{R}$ \\
\hline RWR719 & 15.6 & 2.0 & 44.4 & 3.0 & 51.7 & 4.6 & 35.0 & I \\
\hline $\mathrm{LSD}_{0.05}$ & 29.0 & 0.7 & 28.1 & 1.2 & 45.1 & 1.8 & 8.3 & \\
\hline $\mathrm{CV}(\%)$ & 40.7 & 14.4 & 23.0 & 24.6 & 37.5 & 32.9 & 12.7 & \\
\hline
\end{tabular}

$\mathrm{RC}=$ reaction category; $\mathrm{R}=$ resistant $\mathrm{I}=$ intermediate $\mathrm{S}=$ susceptible; $\mathrm{LSD}=$ least significant difference at $\mathrm{P}$-value threshold of $0.05 ; \mathrm{CV}=$ coefficient of variation 
TABLE 8. Incidence and severity of common bacterial blight on inter-racial elite common bean lines grown in a greenhouse at Kabete, University of Nairobi, Kenya

\begin{tabular}{|c|c|c|c|c|c|c|c|c|}
\hline \multirow[t]{2}{*}{ Genotype } & \multicolumn{2}{|c|}{$\begin{array}{l}14 \text { days } \\
\text { after inoculation }\end{array}$} & \multicolumn{2}{|c|}{$\begin{array}{l}21 \text { days } \\
\text { after inoculation }\end{array}$} & \multicolumn{2}{|c|}{$\begin{array}{l}28 \text { days } \\
\text { afterinoculation }\end{array}$} & \multirow[t]{2}{*}{$\begin{array}{l}\text { Severity } \\
\text { AUDPC }\end{array}$} & \multirow[t]{2}{*}{$\mathrm{RC}$} \\
\hline & $\begin{array}{l}\text { Incidence } \\
(\%)\end{array}$ & Severity & $\begin{array}{l}\text { Incidence } \\
(\%)\end{array}$ & Severity & $\begin{array}{l}\text { Incidence } \\
(\%)\end{array}$ & Severity & & \\
\hline KMA13-17-17 & 0.0 & 1.0 & 0.0 & 1.0 & 0.0 & 1.0 & 14.0 & $\mathrm{R}$ \\
\hline KMA13-17-25 & 12.5 & 1.5 & 50.0 & 3.0 & 50.0 & 4.0 & 36.8 & I \\
\hline KMA13-21-10 & 45.2 & 3.0 & 69.1 & 4.0 & 74.6 & 6.0 & 56.0 & I \\
\hline KMA13-21-11 & 18.8 & 2.0 & 50.0 & 3.0 & 56.3 & 4.0 & 38.5 & I \\
\hline KMA13-21-20 & 56.3 & 4.0 & 56.3 & 4.0 & 62.5 & 7.0 & 59.5 & $\mathrm{~S}$ \\
\hline KMA13-22-21 & 31.3 & 2.5 & 60.7 & 3.5 & 60.7 & 5.0 & 47.2 & I \\
\hline KMA13-22-30 & 75.0 & 4.5 & 75.0 & 3.5 & 75.0 & 5.0 & 54.2 & I \\
\hline KMA13-23-13 & 66.7 & 4.5 & 100.0 & 4.5 & 100.0 & 8.0 & 68.2 & $\mathrm{~S}$ \\
\hline KMA13-23-14 & 58.3 & 4.5 & 83.3 & 4.5 & 83.3 & 6.0 & 61.2 & I \\
\hline KMA13-23-22 & 39.3 & 3.0 & 53.5 & 3.5 & 65.3 & 6.0 & 50.8 & I \\
\hline KMA13-24-7 & 58.4 & 3.5 & 66.7 & 3.5 & 66.7 & 5.0 & 50.8 & I \\
\hline KMA13-25-9 & 33.3 & 2.5 & 33.3 & 3.0 & 44.5 & 5.0 & 42.0 & I \\
\hline KMA13-26-32 & 31.3 & 2.0 & 38.8 & 2.0 & 45.0 & 2.0 & 28.0 & $\mathrm{R}$ \\
\hline KMA13-27-12 & 37.5 & 2.5 & 55.0 & 3.5 & 62.5 & 5.0 & 45.5 & I \\
\hline KMA13-27-27 & 37.5 & 3.5 & 50.0 & 3.5 & 56.3 & 6.0 & 52.5 & I \\
\hline KMA13-27-31 & 37.5 & 2.0 & 37.5 & 1.5 & 37.5 & 2.0 & 22.8 & $\mathrm{R}$ \\
\hline KMA13-28-13 & 43.8 & 3.0 & 43.8 & 2.5 & 43.8 & 5.0 & 42.0 & I \\
\hline KMA13-28-2 & 0.0 & 1.0 & 0.0 & 1.0 & 0.0 & 1.0 & 14.0 & $\mathrm{R}$ \\
\hline KMA13-28-21 & 0.0 & 1.0 & 8.4 & 1.5 & 0.0 & 1.0 & 17.5 & $\mathrm{R}$ \\
\hline KMA13-28-5 & 44.4 & 3.5 & 66.7 & 4.5 & 74.5 & 6.0 & 61.2 & I \\
\hline KMA13-29-21 & 16.7 & 1.5 & 33.3 & 2.0 & 83.3 & 5.0 & 31.5 & I \\
\hline KMA13-29-24 & 75.0 & 3.5 & 87.5 & 3.0 & 87.5 & 5.0 & 49.0 & I \\
\hline KMA13-30-14 & 0.0 & 1.0 & 0.0 & 1.0 & 0.0 & 1.0 & 14.0 & $\mathrm{R}$ \\
\hline KMA13-30-22 & 31.3 & 2.5 & 56.3 & 3.0 & 68.8 & 5.0 & 45.5 & I \\
\hline KMA13-31-62 & 42.9 & 3.5 & 64.3 & 2.5 & 71.4 & 5.0 & 43.8 & I \\
\hline KMA13-32-28 & 25.0 & 3.5 & 35.0 & 3.0 & 36.7 & 6.0 & 47.2 & I \\
\hline AND1062 & 20.0 & 2.0 & 30.0 & 2.5 & 50.0 & 4.0 & 35.0 & I \\
\hline BRB191 & 30.0 & 2.5 & 30.0 & 3.5 & 40.0 & 6.0 & 47.2 & I \\
\hline G10909 & 10.0 & 1.5 & 46.7 & 2.5 & 56.7 & 6.0 & 36.8 & I \\
\hline G2333 & 13.4 & 2.0 & 25.9 & 3.5 & 52.7 & 8.0 & 50.8 & $\mathrm{~S}$ \\
\hline GLP585 & 5.6 & 1.5 & 18.1 & 2.5 & 22.2 & 5.0 & 35.0 & I \\
\hline GLP92 & 46.7 & 3.5 & 75.0 & 3.0 & 76.7 & 5.0 & 47.2 & I \\
\hline KATB1 & 31.3 & 3.5 & 56.3 & 3.0 & 56.3 & 4.0 & 43.5 & I \\
\hline KATB9 & 40.0 & 3.0 & 60.0 & 3.0 & 70.0 & 5.0 & 47.2 & I \\
\hline Mex54 & 52.7 & 5.0 & 72.3 & 5.0 & 79.5 & 8.0 & 71.8 & $\mathrm{~S}$ \\
\hline RWR719 & 41.0 & 2.0 & 42.5 & 2.5 & 47.8 & 4.0 & 35.0 & I \\
\hline $\mathrm{LSD}_{0.05}$ & 37.4 & 1.3 & 31.1 & 1.7 & 26.7 & 2.0 & 17.5 & \\
\hline $\mathrm{CV}(\%)$ & 54.9 & 23.1 & 33.6 & 28.8 & 25.8 & 27.5 & 20.2 & \\
\hline
\end{tabular}

$\mathrm{RC}=$ reaction category; $\mathrm{R}=$ resistant $\mathrm{I}=$ intermediate $\mathrm{S}=$ susceptible; $\mathrm{LSD}=$ least significant difference at $\mathrm{P}$-value threshold of $0.05 ; \mathrm{CV}=$ coefficient of variation 


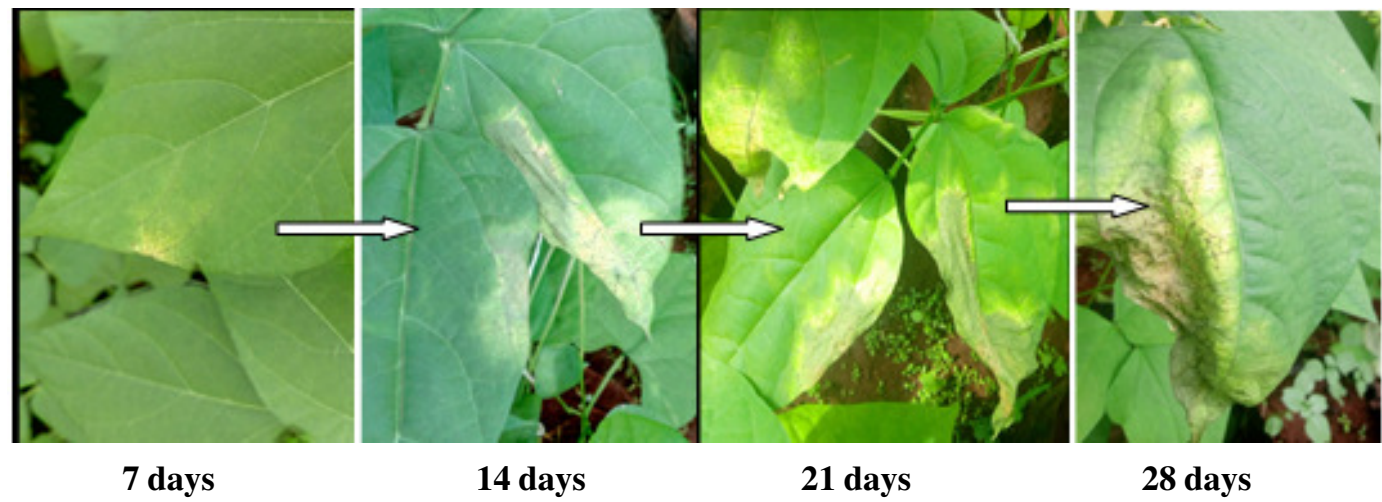

Figure 4. CBB disease progression on susceptible cultivar (Mex54) used as check in a greenhouse at Kabete, University of Nairobi, Kenya.

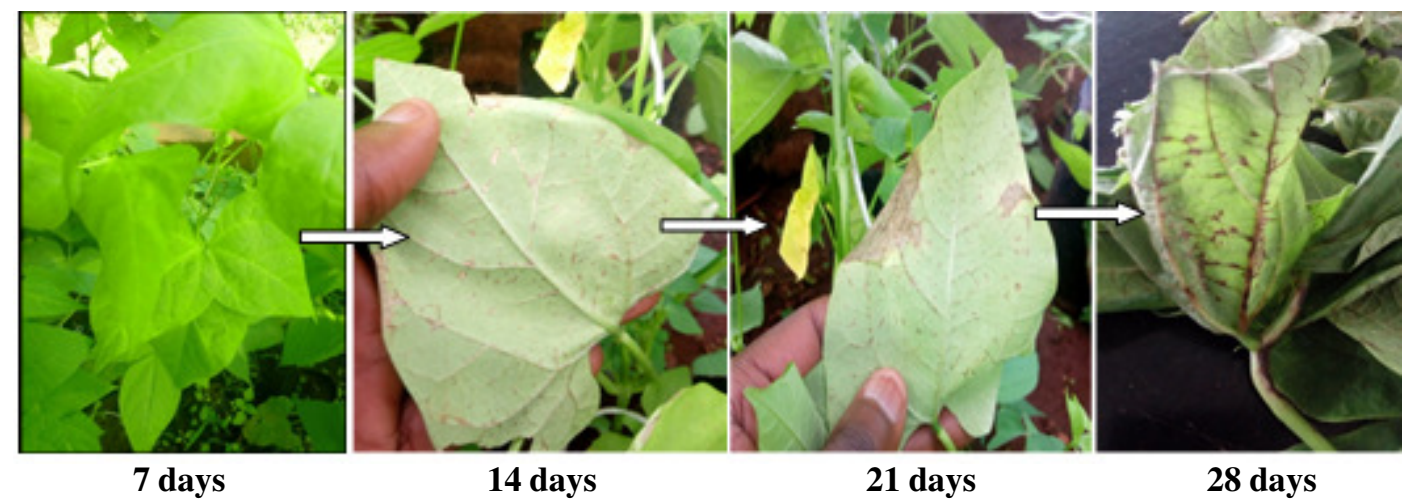

Figure 5. Anthracnose disease progression on susceptible cultivar (KATB1) used as check in a greenhouse at Kabete, University of Nairobi, Kenya.

highest levels of infection were recorded on check varieties KATB1 and KATB9.

Multiple disease resistance in elite lines. All the elite lines possessed resistance to at least one of the pathogens (Table 10). In summary, five of the 26 elite lines possessed a multiple resistance to five pathogens (KMA13-25-9, KMA13-27-31, KMA13-2821, KMA13-28-5, and KMA13-30-14); eight genotypes were resistant to four pathogens (KMA13-17-17, KMA13-23-14, KMA13-2632, KMA13-27-27, KMA13-28-13, KMA1328-2, KMA13-29-21, and KMA13-32-28); nine genotypes were resistant to three pathogens, three of the 26 elite lines possessed resistance to two pathogens and one had resistance to one disease. No significant correlations in reaction of tested genotypes to the seven diseases used in this study (Table 11), except the significant correlation between the BCMV and the ALS ( $\mathrm{r}=0.39 *)$.

\section{DISCUSSION}

Inter-racial crosses and marker-assisted gamete selection method proved to be effective in pyramiding genes for disease resistance to major common bean diseases in Eastern and Central Africa. Up to $96 \%$ of the tested elite lines (25 of the 26) had combined resistance to at least two pathogens; while five lines had 
TABLE 9. Incidence and severity of anthracnose on inter-racial elite common bean lines grown in a greenhouse at Kabete, University of Nairobi, Kenya

\begin{tabular}{|c|c|c|c|c|c|c|c|c|}
\hline \multirow[t]{2}{*}{ Genotype } & \multicolumn{2}{|c|}{$\begin{array}{c}14 \text { Days } \\
\text { after inoculation }\end{array}$} & \multicolumn{2}{|c|}{$\begin{array}{l}21 \text { Days } \\
\text { after inoculation }\end{array}$} & \multicolumn{2}{|c|}{$\begin{array}{l}28 \text { Days } \\
\text { afterinoculation }\end{array}$} & \multirow[t]{2}{*}{$\begin{array}{l}\text { Severity } \\
\text { AUDPC }\end{array}$} & \multirow[t]{2}{*}{$\mathrm{RC}$} \\
\hline & $\begin{array}{c}\text { Incidence } \\
(\%)\end{array}$ & Severity & $\begin{array}{l}\text { Incidence } \\
(\%)\end{array}$ & Severity & $\begin{array}{l}\text { Incidence } \\
(\%)\end{array}$ & Severity & & \\
\hline KMA13-17-17 & 20.0 & 2.0 & 22.0 & 2.0 & 27.0 & 2.0 & 28.0 & $\mathrm{R}$ \\
\hline KMA13-17-25 & 9.0 & 2.0 & 11.0 & 2.0 & 19.0 & 2.0 & 28.0 & $\mathrm{R}$ \\
\hline KMA13-21-10 & 16.7 & 2.0 & 19.0 & 2.0 & 22.0 & 3.0 & 31.5 & $\mathrm{R}$ \\
\hline KMA13-21-11 & 16.7 & 2.0 & 17.5 & 2.0 & 22.0 & 2.0 & 28.0 & $\mathrm{R}$ \\
\hline KMA13-21-20 & 0.0 & 1.0 & 0.0 & 1.0 & 0.0 & 1.0 & 14.0 & $\mathrm{R}$ \\
\hline KMA13-22-21 & 57.1 & 2.0 & 64.0 & 3.0 & 69.0 & 3.0 & 38.5 & $\mathrm{R}$ \\
\hline KMA13-22-30 & 40.0 & 2.0 & 43.0 & 2.0 & 44.0 & 2.0 & 28.0 & $\mathrm{R}$ \\
\hline KMA13-23-13 & 33.3 & 2.0 & 39.0 & 2.0 & 39.0 & 3.0 & 31.5 & $\mathrm{R}$ \\
\hline KMA13-23-14 & 36.4 & 2.0 & 38.0 & 2.0 & 40.0 & 3.0 & 31.5 & $\mathrm{R}$ \\
\hline KMA13-23-22 & 71.4 & 3.0 & 77.0 & 4.0 & 77.0 & 4.0 & 52.5 & I \\
\hline KMA13-24-7 & 75.0 & 3.0 & 87.0 & 3.0 & 100.0 & 3.0 & 42.0 & $\mathrm{R}$ \\
\hline KMA13-25-9 & 0.0 & 1.0 & 0.0 & 1.0 & 11.0 & 2.0 & 17.5 & $\mathrm{R}$ \\
\hline KMA13-26-32 & 40.0 & 2.0 & 48.0 & 2.0 & 52.0 & 2.0 & 28.0 & $\mathrm{R}$ \\
\hline KMA13-27-12 & 18.2 & 2.0 & 20.0 & 2.0 & 26.0 & 2.0 & 28.0 & $\mathrm{R}$ \\
\hline KMA13-27-27 & 22.2 & 2.0 & 25.0 & 2.0 & 27.0 & 2.0 & 28.0 & $\mathrm{R}$ \\
\hline KMA13-27-31 & 0.0 & 1.0 & 0.0 & 1.0 & 11.0 & 2.0 & 17.5 & $\mathrm{R}$ \\
\hline KMA13-28-13 & 37.5 & 2.0 & 38.0 & 3.0 & 40.0 & 3.0 & 38.5 & $\mathrm{R}$ \\
\hline KMA13-28-2 & 14.3 & 2.0 & 15.0 & 2.0 & 19.0 & 2.0 & 28.0 & $\mathrm{R}$ \\
\hline KMA13-28-21 & 0.0 & 1.0 & 0.0 & 1.0 & 0.0 & 1.0 & 14.0 & $\mathrm{R}$ \\
\hline KMA13-28-5 & 10.0 & 2.0 & 15.0 & 2.0 & 22.0 & 2.0 & 28.0 & $\mathrm{R}$ \\
\hline KMA13-29-21 & 0.0 & 1.0 & 0.0 & 1.0 & 0.0 & 1.0 & 14.0 & $\mathrm{R}$ \\
\hline KMA13-29-24 & 16.7 & 2.0 & 18.0 & 2.0 & 24.0 & 2.0 & 28.0 & $\mathrm{R}$ \\
\hline KMA13-30-14 & 20.0 & 2.0 & 22.0 & 2.0 & 32.0 & 3.0 & 31.5 & $\mathrm{R}$ \\
\hline KMA13-30-22 & 50.0 & 2.0 & 55.0 & 2.0 & 62.0 & 2.0 & 28.0 & $\mathrm{R}$ \\
\hline KMA13-31-62 & 11.1 & 2.0 & 15.0 & 2.0 & 17.0 & 2.0 & 28.0 & $\mathrm{R}$ \\
\hline KMA13-32-28 & 0.0 & 1.0 & 9.0 & 2.0 & 14.0 & 2.0 & 24.5 & $\mathrm{R}$ \\
\hline AND1062 & 0.0 & 1.0 & 11.0 & 3.0 & 24.0 & 5.0 & 42.0 & I \\
\hline BRB191 & 6.0 & 2.0 & 17.0 & 4.5 & 22.0 & 5.0 & 56.0 & I \\
\hline G10909 & 25.0 & 2.0 & 30.0 & 2.0 & 37.0 & 2.0 & 28.0 & $\mathrm{R}$ \\
\hline G2333 & 25.0 & 2.0 & 25.0 & 2.5 & 29.0 & 2.5 & 33.2 & $\mathrm{R}$ \\
\hline GLP585 & 27.3 & 2.0 & 32.0 & 3.0 & 38.0 & 3.5 & 40.2 & I \\
\hline GLP92 & 0.0 & 1.0 & 11.0 & 2.0 & 19.0 & 2.0 & 24.5 & $\mathrm{R}$ \\
\hline KATB1 & 16.7 & 3.0 & 18.0 & 5.5 & 25.5 & 6.0 & 70.0 & I \\
\hline KATB9 & 5.5 & 2.5 & 14.5 & 5.5 & 25.5 & 5.5 & 66.5 & I \\
\hline Mex54 & 0.0 & 1.0 & 0.0 & 1.0 & 12.0 & 2.0 & 17.5 & $\mathrm{R}$ \\
\hline RWR719 & 11.1 & 2.0 & 14.0 & 2.0 & 16.0 & 3.0 & 31.5 & $\mathrm{R}$ \\
\hline $\mathrm{LSD}_{0.05}$ & 2.6 & 1.0 & 1.7 & 2.8 & 2.9 & 3.1 & 33.6 & \\
\hline $\mathrm{CV}(\%)$ & 6.2 & 25.6 & 3.4 & 60.7 & 5.0 & 59.1 & 52.1 & \\
\hline
\end{tabular}

$\mathrm{RC}=$ reaction category; $\mathrm{R}=$ resistant $\mathrm{I}=$ intermediate; $\mathrm{S}=$ susceptible; $\mathrm{LSD}=$ least significant difference at $\mathrm{P}$-value threshold of $0.05 ; \mathrm{CV}=$ coefficient of variation 
TABLE 10. Multiple disease resistance of elite common bean lines grown in a greenhouse at Kabete, University of Nairobi, Kenya

\begin{tabular}{|c|c|c|c|c|c|c|c|c|c|}
\hline \multirow[t]{2}{*}{ Genotypes } & \multicolumn{7}{|c|}{${ }^{1}$ Pathogens } & \multirow[t]{2}{*}{${ }^{2}$ Resistances } & \multirow[t]{2}{*}{ Numbe } \\
\hline & ALS & BCMV & $\mathrm{CBB}$ & ANT & Fusarium & Rhizoctonia & Pythium & & \\
\hline KMA13-17-17 & $\mathrm{R}$ & I & $\mathrm{R}$ & $\mathrm{R}$ & I & $\mathrm{R}$ & I & $\mathrm{A}, \mathrm{C}, \mathrm{AN}, \mathrm{R}$ & 4 \\
\hline KMA13-17-25 & $\mathrm{R}$ & I & I & $\mathrm{R}$ & $\mathrm{S}$ & $\mathrm{R}$ & I & $\mathrm{A}, \mathrm{AN}, \mathrm{R}$ & 3 \\
\hline KMA13-21-10 & I & I & I & $\mathrm{R}$ & I & $\mathrm{R}$ & I & $\mathrm{AN}, \mathrm{R}$ & 2 \\
\hline KMA13-21-11 & I & I & I & $\mathrm{R}$ & $\mathrm{S}$ & $\mathrm{R}$ & $\mathrm{R}$ & AN, R, P & 3 \\
\hline KMA13-21-20 & $\mathrm{R}$ & I & S & $\mathrm{R}$ & I & I & I & $\mathrm{A}, \mathrm{AN}$ & 2 \\
\hline KMA13-22-21 & I & $\mathrm{R}$ & I & $\mathrm{R}$ & I & I & $\mathrm{R}$ & $\mathrm{B}, \mathrm{AN}, \mathrm{P}$ & 3 \\
\hline KMA13-22-30 & I & I & I & $\mathrm{R}$ & I & I & I & ANT & 1 \\
\hline KMA13-23-13 & I & $\mathrm{R}$ & $\mathrm{S}$ & $\mathrm{R}$ & I & $\mathrm{R}$ & I & $\mathrm{B}, \mathrm{AN}, \mathrm{R}$ & 3 \\
\hline KMA13-23-14 & $\mathrm{R}$ & I & I & $\mathrm{R}$ & I & $\mathrm{R}$ & $\mathrm{R}$ & A, R,AN, P & 4 \\
\hline KMA13-23-22 & I & $\mathrm{R}$ & I & I & I & $\mathrm{R}$ & I & $\mathrm{B}, \mathrm{R}$ & 2 \\
\hline KMA13-24-7 & $\mathrm{R}$ & I & I & $\mathrm{R}$ & I & $\mathrm{R}$ & I & $\mathrm{A}, \mathrm{AN}, \mathrm{R}$ & 3 \\
\hline KMA13-25-9 & $\mathrm{R}$ & $\mathrm{R}$ & I & $\mathrm{R}$ & I & $\mathrm{R}$ & $\mathrm{R}$ & $\mathrm{A}, \mathrm{B}, \mathrm{AN}, \mathrm{R}, \mathrm{P}$ & 5 \\
\hline KMA13-26-32 & $\mathrm{R}$ & I & $\mathrm{R}$ & $\mathrm{R}$ & I & $\mathrm{R}$ & I & $\mathrm{A}, \mathrm{C}, \mathrm{AN}, \mathrm{R}$ & 4 \\
\hline KMA13-27-12 & $\mathrm{R}$ & $\mathrm{R}$ & I & $\mathrm{R}$ & I & $\mathrm{I}$ & I & $\mathrm{A}, \mathrm{AN}, \mathrm{B}$ & 3 \\
\hline KMA13-27-27 & $\mathrm{R}$ & $\mathrm{R}$ & I & $\mathrm{R}$ & I & $\mathrm{R}$ & I & $\mathrm{A}, \mathrm{B}, \mathrm{AN}, \mathrm{R}$ & 4 \\
\hline KMA13-27-31 & $\mathrm{R}$ & I & $\mathrm{R}$ & $\mathrm{R}$ & $\mathrm{R}$ & $\mathrm{R}$ & I & $\mathrm{A}, \mathrm{C}, \mathrm{AN}, \mathrm{F}, \mathrm{R}$ & 5 \\
\hline KMA13-28-13 & $\mathrm{R}$ & $\mathrm{R}$ & I & $\mathrm{R}$ & $\mathrm{S}$ & $\mathrm{R}$ & I & $\mathrm{A}, \mathrm{B}, \mathrm{AN}, \mathrm{R}$ & 4 \\
\hline KMA13-28-2 & $\mathrm{R}$ & I & $\mathrm{R}$ & $\mathrm{R}$ & I & $\mathrm{R}$ & I & $\mathrm{A}, \mathrm{C}, \mathrm{AN}, \mathrm{R}$ & 4 \\
\hline KMA13-28-21 & $\mathrm{R}$ & $\mathrm{R}$ & $\mathrm{R}$ & $\mathrm{R}$ & I & I & $\mathrm{R}$ & $\mathrm{A}, \mathrm{B}, \mathrm{C}, \mathrm{AN}, \mathrm{P}$ & 5 \\
\hline KMA13-28-5 & $\mathrm{R}$ & $\mathrm{R}$ & I & $\mathrm{R}$ & I & $\mathrm{R}$ & $\mathrm{R}$ & $\mathrm{A}, \mathrm{B}, \mathrm{AN}, \mathrm{R}, \mathrm{P}$ & 5 \\
\hline KMA13-29-21 & $\mathrm{R}$ & $\mathrm{R}$ & I & $\mathrm{R}$ & I & $\mathrm{R}$ & I & $\mathrm{A}, \mathrm{B}, \mathrm{AN}, \mathrm{R}$ & 4 \\
\hline KMA13-29-24 & I & $\mathrm{R}$ & I & $\mathrm{R}$ & I & $\mathrm{R}$ & I & $\mathrm{B}, \mathrm{AN}, \mathrm{R}$ & 3 \\
\hline KMA13-30-14 & I & $\mathrm{R}$ & $\mathrm{R}$ & $\mathrm{R}$ & I & $\mathrm{R}$ & $\mathrm{R}$ & $\mathrm{B}, \mathrm{C}, \mathrm{AN}, \mathrm{R}, \mathrm{P}$ & 5 \\
\hline KMA13-30-22 & $\mathrm{R}$ & I & I & $\mathrm{R}$ & I & $\mathrm{R}$ & I & $\mathrm{A}, \mathrm{AN}, \mathrm{R}$ & 3 \\
\hline KMA13-31-62 & $\mathrm{R}$ & $\mathrm{R}$ & I & $\mathrm{R}$ & I & $\mathrm{I}$ & I & $\mathrm{A}, \mathrm{B}, \mathrm{AN}$ & 3 \\
\hline KMA13-32-28 & $\mathrm{R}$ & I & I & $\mathrm{R}$ & I & $\mathrm{R}$ & $\mathrm{R}$ & $\mathrm{A}, \mathrm{AN}, \mathrm{R}, \mathrm{P}$ & 4 \\
\hline
\end{tabular}


TABLE 11. Pearson's correlation coefficients among pathogens for disease resistance of inter-racial elite common bean lines grown in a greenhouse at Kabete, University of Nairobi, Kenya

\begin{tabular}{llccccc}
\hline Pathogens & ALS & ANT & BCMV & CBB & FRR & PRR \\
\hline ANT & $0.16^{\text {ns }}$ & & & & & \\
BCMV & $0.39^{*}$ & $-0.11^{\text {ns }}$ & & & & \\
CBB & $0.12^{\text {ns }}$ & $0.03^{\text {ns }}$ & $0.18^{\text {ns }}$ & & & \\
FRR & $-0.18^{\text {ns }}$ & $-0.02^{\text {ns }}$ & $-0.07^{\text {ns }}$ & $0.18^{\text {ns }}$ & & \\
PRR & $-0.19^{\text {ns }}$ & $0.04^{\text {ns }}$ & $0.07^{\text {ns }}$ & $-0.10^{\text {ns }}$ & $0.08^{\text {ns }}$ & \\
RRR & $-0.01^{\text {ns }}$ & $-0.07^{\text {ns }}$ & $-0.22^{\text {ns }}$ & $0.03^{\text {ns }}$ & $0.07^{\text {ns }}$ & $-0.20^{\text {ns }}$ \\
\hline
\end{tabular}

ns = not significant; $*$ = significant at $0.05 \mathrm{P}$-value threshold; ALS = angular leaf spot; ANT = anthracnose; $\mathrm{BCMV}=$ bean common mosaic virus; $\mathrm{CBB}=$ common bacterial blight; $\mathrm{FRR}=$ Fusarium root rot; PRR = Pythium root rot; RRR = Rhizoctonia root rot

multiple resistance to five pathogens (Table 10). This implies that markers are effective in identifying and transferring of resistance genes to susceptible commercial varieties in early generations. Pyramiding genes for disease resistance in a genotype is a more durable and sustainable strategy to control diseases, as multiple coinfections of pathogens are common in production fields and have been reported to substantially affect productivity of the common bean (Singh, 2001; Valentini et al., 2017; Okii et al., 2018).

While developing inter-gene pool multipleparent genotypes, Okii et al. (2017) showed the effectiveness of marker-assisted selection to pyramid genes of resistance as well as improve the agronomic qualities. In their study, disease resistance was associated with smallseeded Mesoamerican genotypes, except for the BCMV where the Andean and Mesoamerican genotypes behaved similarly. This could explain the growing interest in interracial crosses among genotypes belonging to these two gene pools. Thus, the low levels of disease infection recorded on test elite lines in the greenhouse could be attributed to effects of inter-gene and inter-racial crosses performed between Andean and Mesoamerican cultivars as they allowed to broaden the genetic base and increase levels of resistance to both biotic and abiotic stresses (Welsh et al., 1995;
Singh et al., 2002; Singh and Schwartz, 2010; Singh, 2013).

Gamete selection method was effective as it allowed pyramiding resistance genes to target pathogens, and thus reached the primary objective of this breeding programme, which was to ascertain the effectiveness of the gamete selection in pyramiding resistance genes to major bean diseases in Eastern Africa in susceptible popular cultivars.

Many other successful applications of the gamete selection to improve the common bean disease resistance have been reported (Singh et al., 1998; Asensio-S.-Manzanera et al., 2005; 2006; Singh et al., 2008; Terán and Singh, 2009). The innovation of using markers on the gamete selection during this breeding programme allowed to increase precision and efficiency, and therefore, made it easy to pyramid desirable genes as previously stated by Miklas et al. (2006).

There was an independent inheritance of genes controlling the major common bean diseases, as no significant correlations were reported among them (no co-segregation of resistance genes), except the significant correlation between the BCMV and the ALS (Table 11).

More surprising were reactions of elite lines to root rot-causing agents (Table 5). Fusarium root rot was the most damaging among 
common bean root rots, both for disease incidence and severity. Only one elite line from the 26 tested and one check variety of the 10 used were resistant to Fusarium root rot. A study carried out by Mukankusi (2008) confirmed the virulence the Fusarium root rot as, among the 147 accessions evaluated in that study, none of them showed resistance to this pathogen. Spence (2003) found that $F$. solani was more damaging than the two common species of Pythium (P. torulosum and $P$. spinosum) in Uganda.

Although the plant materials used in the present study were improved for Pythium root rot resistance, its incidence and severity were still very high. Only eight out of 26 elite lines possessed the Pythium root rot resistance. None of the genotypes had shown concurrent resistance to Pythium and Fusarium root rot, even though the parental line RWR719, which was used in study populations, has been reported to possess genes of resistance to both pathogens (Otsyula et al., 2003; Mukankusi, 2015). Similar results were reported by Mukankusi et al. (2018) as only $21.5 \%$ of tested inter-specific lines combined concurrent resistance to Fusarium and Pythium root rot. These results supported those of Ongom et al. (2012), who concluded that although quantitative trait loci (QTLs) linked to Fusarium solani resistance have been mapped on the same chromosome as that for resistance to Pythium ultimum, their resistances were inherited independently and the correlations between them were very low (Table 11). In addition, resistance to Fusarium solani is believed to be much more complex as it is controlled by two or more genes (Mukankusi et al., 2011; Obala et al., 2012); while the Pythium ultimum resistance is only conditioned by a single dominant gene, marked by a dominant SCAR marker-PYAA $19^{800}$ (Otsyula et al., 2003; Mahuku et al., 2005; Otsyula, 2010). This could explain why breeding for Pythium root rot resistance did not improve significantly the Fusarium root rot resistance, even if a donor parent
(RWR719) resistant to both pathogens was involved in the crosses.

\section{CONCLUSION}

This study has confirmed the effectiveness of inter-racial crosses and marker-assisted gamete selection to concurrently improve resistance of common bean to major diseases in Eastern and Central Africa. From the 26 elite lines tested in this experiment, five lines possess a concurrent resistance to five pathogens; eight are resistant to four pathogens; nine are resistant to three pathogens, three show resistance to two pathogens and one has a resistance to one pathogen.

Efficient use of markers in the gamete selection method at early generations is effective for pyramiding resistance genes into susceptible genotypes. However, there are no significant correlations in the reaction of tested genotypes to pathogens used in this study, except the significant correlation between the reaction of genotypes to BCMV and the ALS. This suggests that most of the genes controlling resistance to these major bean diseases are inherited independently.

Further field experiments in areas with a high prevalence of these diseases should be conducted to confirm the multiple disease resistance of these elite lines before releasing to farmers. In addition, more sources of resistance to these pathogens should be sought and introgressed for durable resistance, especially to CBB and Fusarium root rot.

\section{ACKNOWLEDGMENT}

Financial support from the Université Evangélique en Afrique is gratefully acknowledged.

\section{REFERENCES}

Alladassi, B.M.E., Nkalubo, S.T., Mukankusi, C., Kayaga, H.N., Gibson, P., Edema, R., 
Urrea, C.A., Kelly, J.D. and Rubaihayo, P.R. 2018. Identification of common bean genotypes with dual leaf and pod resistance to common bacterial blight disease in Uganda. African Crop Science Journal 26(1):63-77.

Asensio, S.M.M.C., Asensio, C. and Singh, S.P. 2006. Gamete selection for resistance to common and halo bacterial blights in dry bean inter-gene pool populations. Crop Science 46(1):131-135.

Asensio-S.-Manzanera, M.C., Asensio, C. and Singh, S.P. 2005. Introgressing resistance to bacterial and viral diseases from the Middle American to Andean common bean. Euphytica 143(1-2):223-228.

Asfaw, A., Blair, M.W. and Almekinders, C. 2009. Genetic diversity and population structure of common bean (Phaseolus vulgaris L.) landraces from the East African highlands. Theoretical and Applied Genetics 120(1):1-12.

Beaver, J.S. and Osorno, J.M. 2009. Achievements and limitations of contemporary common bean breeding using conventional and molecular approaches. Euphytica 168:145-175.

Beebe, S., Rao, I.M., Blair, M.W. and AcostaGallegos, J.A. 2013. Phenotyping common beans for adaptation to drought. Frontiers in physiology 4:35.

Bigirimana, J. and Höfte, M. 2001. Bean anthracnose: inoculation methods and influence of plant stage on resistance of Phaseolus vulgaris cultivars. Journal of Phytopathology 149(7 8):403-408.

Broughton, W.J., Hernandez, G., Blair, M., Beebe, S., Gepts, P. and Vanderleyden, J. 2003. Beans (Phaseolus spp.)-model food legumes. Plant and soil 252(1):55-128.

Buruchara, R., Estevez de Jensen, C., Godoy, G., Abawi, G., Pasche, J., Lobo Junior, M. and Mukankusi, C. 2015. A review of the root rot diseases of common bean with emphasis in Latin America and Africa, Conference paper, July 20-23, 2015,
Protea Hotel, Kruger Gate Skukuza, South Africa.

Campbell, C.L. and Madden, L.V. 1990. Introduction to plant disease epidemiology. John Wiley \& Sons, New York. 532pp.

CGIAR. 2017. Ten year research strategy for pulse crops. http://grainlegumes.cgiar.org/ wp-content/uploads/2017/01/IYP_10Year-Research-Strategy_PulseCrops_Final_Dec-8-20162.pdf Accessed 5th March 2018.

Correa, F.J. and Saettler, A.W. 1987. Angular leaf spot of red kidney beans in Michigan. Plant disease 71(10):915-918.

Ddamulira, G., Mukankusi, C., OchwoSsemakula, M., Edema, R., Sseruwagi, P. and Gepts, P. 2014. Identification of new sources of resistance to angular leaf spot among Uganda common bean landraces. Canadian Journal of Plant Breeding 2(2):55-65.

De Queiroz, V.T., De Sousa, C.S., Costa, M.R., Sanglad, D.A., Arruda, K.M.A., De Souza, T.L.P.O., Ragagnin, V.A., De Barros, E.G. and Moreira, M.A. 2004. Development of SCAR markers linked to common bean angular leaf spot resistance genes. Annual Report-Bean Improvement Cooperative 47:237-238.

FAO. 2018. FAOSTAT: FAO Statistical Databases. Available online at: http:// faostat.fao.org/

Garzón, L.N., Ligarreto, G.A. and Blair, M.W. 2008. Molecular marker-assisted backcrossing of anthracnose resistance into Andean climbing beans (Phaseolus vulgaris L.). Crop Science 48(2):562-570.

Harveson, R.M. and Schwartz, H.F. 2007. Bacterial diseases of dry edible beans in the Central High Plains. Plant Health Progress 8(1):35. doi:10.1094/PHP-2007-0125-01DG

Jaetzold, R., Schmidt, H., Hornetz, B. and Shisanya, C. 2006. Farm Management Handbook of Kenya. Vol II, Natural conditions and farm management 
information, $2^{\text {nd }}$ Edition Part B Central Kenya. Subpart B2. Central Province.

Kilimo, Trust. 2012. Development of inclusive markets in agriculture and trade (DIMAT): The nature and markets of bean value chains in Uganda. United National Development Program (UNDP) Government of Uganda (GoU) Kilimo Trust, Kampala, Uganda, p.56.

Kimani, P.M., Buruchara, R., Muthamia, J., Mbikayi, N., Asfaw, A., Namayanja, A., Rachier, G., Otsyula, R. and Lunze, L. 2005a. Selection on marketable bean lines with improved resistance to angular leaf spot, root rots and yield for smallholder farmers in ECA. Presented at the Second Biotechnology, Breeding and Seed Systems Conference, January 2005, Rockefeller Foundation, Nairobi, Kenya, pp. 23-27.

Kimani, P.M., Buruchara, R., Ampofo, K., Pyndji, M., Chirwa, R. and Kirkby, R. 2005b. Breeding beans for smallholder farmers in Eastern, Central and Southern Africa: Constraints, achievements and potential. In: Pan-African Bean Research Network (PABRA) Millennium Workshop, 28 May-1 June, Arusha, Tanzania, pp. 1128.

Kiryowa, M.J., Ebinu, A., Kyaligonza, V., Nkalubo, S.T., Paparu, P., Mukankusi, C. and Tukamuhabwa, P. 2016. Pathogenic variation of Colletotrichum lindemuthianum causing anthracnose of beans (Phaseolus vulgaris) in Uganda. International Journal of Phytopathology 5(3):89-98.

Leitich, R.K., Arinaitwe, W., Mukoye, B., Omayio, D.O., Osogo, A.K., Were, H.K., Muthomi, J.W., Otsyula, R.M. and Abang, M.M. 2016. Mapping of Angular Leaf Spot Disease Hotspot Areas in Western Kenya Towards Its Management. American Journal of Applied Scientific Research 2(6):75-81.

Mahuku, G., Buruchara, R., Navia, M. and Otsyula, R. 2005. A gene that confers resistance to Pythium root rot in common bean: Genetic characterization and development of molecular markers. CIAT poster Publication. Retrieved from http:// webapp.ciat.cgiar.org/ipm/pdfs /poster_ aps_2005_mahuku.pdf

Mahuku, G.S., Henríquez, M.A., Montoya, C., Jara, C., Teran, H. and Beebe, S. 2011. Inheritance and development of molecular markers linked to angular leaf spot resistance genes in the common bean accession G10909. Molecular Breeding 28(1):57-71.

Miklas, P.N., Kelly, J.D., Beebe, S.E. and Blair, M.W. 2006. Common bean breeding for resistance against biotic and abiotic stresses: from classical to MAS breeding. Euphytica 147(1-2):105-131.

Mondo, M.J., Kimani, P.M. and Narla, R.D. 2018. Marker-assisted gamete selection for multiple disease resistance and grain yield in inter-gene pool and inter-racial populations of common bean. African Journal of Rural Development 3 (4): 931941.

Mondo, J.M., Kimani, P.M. and Narla, R.D. 2019a. Genotype x environment interactions on seed yield of inter-racial common bean lines in Kenya. World Journal of Agricultural Research 7(3):7687.

Mondo, J.M., Kimani, P.M. and Narla, R.D. 2019b. Yield stability in small red interracial common bean lines in Kenya. African Crop Science Journal 27(3):351-374.

Mukankusi, C. 2008. Improving resistance to Fusarium root rot [Fusariun solani (mart) Sacc. f. sp. phaseoli (Burkholder) W.C Snyder \& H.E Hans] in common beans (Phaseolus vulgaris L.). PhD Thesis, University of KwaZulu-Natal, Pietermaritzburg, South Africa.

Mukankusi, C. 2015. Breeding for root rot resistance in East and Central Africa. http:/ /arsftfbean.uprm.edu/bean/wp-content/ uploads/2015/09/BDW-Day2-ClareMukankusi.pdf 
Mukankusi, C., Derera, J., Melis, R., Gibson, P.T. and Buruchara, R. 2011. Genetic analysis of resistance to Fusarium root rot in common bean. Euphytica 182(1):11.

Mukankusi, C.M., Amongi, W., Sebuliba, S., Musoke, S. and Acam, C. 2018. Characterisation of Phaseolus coccineus interspecific germplasm accessions for disease resistance, grain market class and yield attributes. African Crop Science Journal 26(1):117-135.

Musyimi, A.S. 2014. Marker-Assisted Gamete Selection for Multiple Disease Resistance in Andean Bean Genotypes and Characterization of Colletotrichum lindemuthianum in Kenya. M.Sc. diss., University of Nairobi, Kenya, p. 234.

Mwaipopo, B., Nchimbi-Msolla, S., Njau, P., Tairo, F., William, M., Binagwa, P., Kweka, E., Kilango, M. and Mbanzibwa, D. 2017. Viruses infecting common bean (Phaseolus vulgaris L.) in Tanzania: A review on molecular characterization, detection and disease management options. African Journal of Agricultural Research 12(18):1486-1500.

Mwang'ombe, A.W., Wagara, I.N., Kimenju, J.W. and Buruchara, R.A. 2007. Occurrence and Severity of Angular leaf spot of common bean in Kenya as influenced by geographical location, altitude and agroecological zones. Plant Pathology Journal 6(3):235-241.

Namayanja, A., Msolla, S.N., Buruchara, R. and Namusoke, A. 2014. Genetic Analysis of Resistance to Pythium Root Rot Disease in Common Bean (Phaseolus vulgaris L.) Genotypes. Journal of Crop Improvement 28(2):184-202.

Njuguna, S.M. 2014. Marker-assisted gamete selection for multiple disease resistance in Mesoamerican bean genotypes and race typing of angular leaf spot pathogen in Kenya. M.Sc. diss., University of Nairobi, Kenya, p. 246.

Nzungize, J., Gepts, P., Buruchara, R., Male, A., Ragama, P., Busogoro, J.P. and Baudoin,
J.P., 2011a. Introgression of Pythium root rot resistance gene into Rwandan susceptible common bean cultivars. African Journal of Plant Science 5(3):193200.

Nzungize, J., Gepts, P., Buruchara, R., Buah, S., Ragama, P., Busogoro, J.P. and Baudoin, J.P., 2011b. Pathogenic and molecular characterization of Pythium species inducing root rot symptoms of common bean in Rwanda. African Journal of Microbiology Research 5:1169-1181.

Obala, J., Mukankusi, C., Rubaihayo, P.R., Gibson, P. and Edema, R. 2012. Improvement of resistance to Fusarium root rot through gene pyramiding in common bean. African Crop Science Journal 20(1):1-13.

Odogwu, B.A., Nkalubo, S.T., Mukankusi, C., Odong, T., Awale, H.E., Rubaihayo, P. and Kelly, J.D. 2017. Phenotypic and genotypic screening for rust resistance in common bean germplasm in Uganda. Euphytica 213(2):49.

Okii, D., Mukankusi, C., Sebuliba, S., Tukamuhabwa, P., Tusiime, G., Talwana, H., Odong, T., Namayanja, A., Paparu, P., Nkalubo, S. and Otim, M. 2018. Genetic variation, Heritability estimates and GXE effects on yield traits of Mesoamerican common bean (Phaseolus vulgaris L) germplasm in Uganda. Plant Genetic Resources 16(3):237-248.

Okii, D., Tukamuhabwa, P., Tusiime, G., Talwana, H., Odong, T., Mukankusi, C., Male, A., Amongi, W., Sebuliba, S., Paparu, P. and Nkalubo, S. 2017. Agronomic qualities of genetic pyramids of common bean developed for multiple-diseaseresistance. African Crop Science Journal 25(4):457-472.

Omunyin, M.E., Gathuru, E.M. and Mukunya, D.M. 1995. Pathogenicity groups of bean common mosaic virus isolates in Kenya. Plant Disease 79:985-989.

Ongom, P.O., Nkalubo, S.T., Gibson, P.T., Mukankusi, C.M. and Rubaihayo, P.R. 
2012. Evaluating genetic association between Fusarium and Pythium root rots resistances in the bean genotype RWR 719. African Crop Science Journal 20(1):31-39.

Otsyula, R.M. 2010. Nature of genetic control and inheritance of resistance to Pythium root rot in bean genotypes. PhD Thesis, Makerere University, Kampala, Uganda.

Otsyula, R.M., Buruchara, R.A., Mahuku, G. and Rubaihayo, P. 2003. Inheritance and transfer of root rot (Pythium) resistance to bean genotypes. http://ciatlibrary.ciat.cgiar.org/Articulos Ciat/ipm/ pdfs/reuben 2.pdf.

Ronner, E., Descheemaeker, K., Almekinders, C.J., Ebanyat, P. and Giller, K.E. 2018. Farmers' use and adaptation of improved climbing bean production practices in the highlands of Uganda. Agriculture, Ecosystems \& Environment 261:186-200.

Schoonhoven, A.V. and Pastor-Corrales, M.A. 1987. Standard system for the evaluation of bean germplasm. CIAT, Cali, Colombia, 56.

Sharma, P.N., Pathania, A., Kapil, R., Sharma, P., Sharma, O.P., Patial, M. and Kapoor, V. 2008. Resistance to bean common mosaic potyvirus strains and its inheritance in some Indian landraces of common bean. Euphytica 164(1):173-180.

Sicard, D., Buchet, S., Michalakis, Y. and Neema, C. 1997. Genetic variability of Colletotrichum lindemuthianum in wild populations of common bean. Plant Pathology 46(3):355-365.

Sichilima, T., Mapemba, L. and Tembo, G., 2016. Drivers of dry common beans trade in Lusaka, Zambia: A trader's perspective. Sustainable Agriculture Research 5(2):15.

Singh, S.P. 1994. Gamete selection for simultaneous improvement of multiple traits in common bean. Crop Science 34(2):352-355.
Singh, S.P. 2013. Common bean improvement in the twenty-first century (Vol. 7). Springer Science \& Business Media.

Singh, S.P. and Schwartz, H.F. 2010. Breeding common bean for resistance to diseases: a review. Crop Science 50(6):2199-2223.

Singh, S.P., 2001. Broadening the genetic base of common bean cultivars. Crop Science 41(6):1659-1675.

Singh, S.P., Cardona, C., Morales, F.J., Pastor-Corrales, M.A. and Voysest, O. 1998. Gamete selection for upright carioca bean with resistance to five diseases and a leafhopper. Crop Science 38(3):666-672.

Singh, S.P., Terán, H., Lema, M., Dennis, M.F., Hayes, R. and Robinson, C. 2008. Breeding for slow-darkening, high-yielding, broadly adapted dry bean pinto 'Kimberly' and 'Shoshone'. Journal of Plant Registrations 2(3):180-186.

Singh, S.P., Terán, H., Muñoz, C.G. and Osorno, J.M. 2002. Selection for seed yield in Andean intra-gene pool and Andeanx Middle American inter-gene pool populations of common bean. Euphytica 127(3):437-444.

Spence, N. 2003. Characterization and epidemiology of root rot diseases caused by Fusarium and Pythium sp. in beans in Uganda. Final technical report, R7568 (ZA0373). Horticultural Research International, Wellesbourne, Warwick, CV 35, 9EF UK.

Strausbaugh, C.A., Myers, J.R., Forster, R.L. and McClean, P.E. 1999. bc-1 and bc-utwo loci controlling bean common mosaic virus resistance in common bean are linked. Journal of the American Society for Horticultural Science 124(6):644-648.

Terán, H. and Singh, S.P. 2009. Gamete selection for improving physiological resistance to white mold in common bean. Euphytica 167(3):271-280.

Valentini, G., Gonçalves-Vidigal, M.C., Cregan, P.B., Song, Q. and Pastor-Corrales, M.A. 
2017. Simple sequence repeat DNA markers linked with genes for resistance to major diseases of common bean. Publications from USDA-ARS / UNL Faculty. 1659.

Verma, P. and Gupta, U.P. 2010. Immunological detection of bean common mosaic virus in French bean (Phaseolus vulgaris L.) leaves. Indian Journal of Microbiology 50(3):263-265.

VSN International. 2013. Genstat for Windows (15 ${ }^{\text {th }}$ Edition), Oxford, UK.

Wagara, I.N., Mwang'ombe, A.W. and Siboe, G.M. 1999. Colonisation of resistant and susceptible bean tissues by Phaeoisariopsis griseola (Sacc) Ferr. African Crop Science Journal 7(4):523-530.
Welsh, W., Bushuk, W., Roca, W. and Singh, S.P. 1995. Characterization of agronomic traits and markers of recombinant inbred lines from intra-and interracial populations of Phaseolus vulgaris L. Theoretical and Applied Genetics 91(1):169-177.

White, J.G. 1988. Studies on the biology and control of cavity spot of carrots. Annals of Applied Biology 113(2):259-268.

Winham, D.M., Hutchins, A.M., Thompson, S.V. and Dougherty, M.K. 2018. Arizona registered dietitians show gaps in knowledge of bean health benefits. Nutrients 10(1):52.

Wortmann, C.S. 1998. Atlas of common bean (Phaseolus vulgaris L.) production in Africa (No. 297). CIAT, Cali, Colombia. 